\title{
Supergénne minerály z U-Cu rudného výskytu Východná- Nižný Chmelienec v Nízkych Tatrách (hronikum, Slovensko)
}

\author{
Supergene minerals from the U-Cu ore occurrence Východná-Nižný Chmelienec, \\ the Nízke Tatry Mts. (Hronic Unit, Slovakia)
}

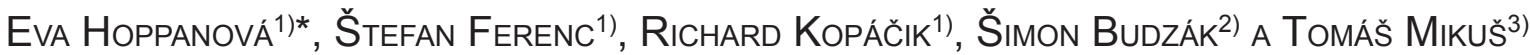 \\ 1)Katedra geografie a geológie, Fakulta prírodných vied, Univerzita Mateja Bela, Tajovského 40, 97401 Banská \\ Bystrica, Slovenská republika; *e-mail: eva.hoppanova@umb.sk \\ 2)Katedra chémie, Fakulta prírodných vied, Univerzita Mateja Bela, Tajovského 40, 97401 Banská Bystrica, \\ Slovenská republika \\ 3) Ústav vied o Zemi, Slovenská akadémia vied, Ďumbierska 1, 97411 Banská Bystrica, Slovenská republika
}

Hoppanová E, Ferenc Š, KopÁČIK R, BudzÁK Š, MıKuš T (2021) Supergénne minerály z U-Cu rudného výskytu VýchodnáNižný Chmelienec v Nízkych Tatrách (hronikum, Slovensko). Bull Mineral Petrolog 29(1): 77-89 ISSN 2570-7337

\begin{abstract}
An association of supergene U-Cu and Y/REE minerals was found in a relic of old ore dump at the abandoned U deposit occurrence Východná-Nižný Chmelienec, the northern slopes of the Nízke Tatry Mts., Slovakia. They have partially recent origin, since exploration of the locality took place between 1965 and 1966 . The studied mineral assemblage is represented by goethite, malachite, uranophane and (meta)zeunerite, in a lesser extent baryte and rare zálesíite. Uranophane appears separately (globular aggregates, thin coatings) and it also forms the main part of the yellow to yellow-green crystalline crusts on the rock cracks. The chemical composition of the uranophane was determined by electron microprobe analyses and it is close to its ideal chemical formula $\mathrm{Ca}\left(\mathrm{UO}_{2}\right)_{2}\left(\mathrm{SiO}_{3} \mathrm{OH}\right)_{2} \cdot 5 \mathrm{H}_{2} \mathrm{O}$. The average chemical composition of the studied uranophane can be expressed by an empirical formula $\left(\mathrm{Ca}_{10} \mathrm{Mg}_{002} \mathrm{~K}_{001} \mathrm{Fe}_{001} \mathrm{Ba}_{001}\right)_{\Sigma 1.05}$ $\left(\mathrm{UO}_{2}\right)_{2.08}\left(\mathrm{SiO}_{3} \mathrm{OH}\right)_{1.84} \cdot 5 \mathrm{H}_{2} \mathrm{O}$. The infrared vibrational spectra of the studied uranophane show $\mathrm{v}_{3}\left(\mathrm{UO}_{2}\right)^{2+}$ at $850-760 \mathrm{~cm}^{-1}$; the $v_{3}\left(\mathrm{SiO}_{4}\right)^{4-}$ antisymmetric stretching vibration at $1000-900 \mathrm{~cm}^{-1}$; the $v_{1}\left(\mathrm{SiO}_{4}\right)^{4-}$ symmetric stretching vibration at 1150-1199 $\mathrm{cm}^{-1}$; the $\delta \mathrm{H}_{2} \mathrm{O}$ bending vibration at 1800-1600 $\mathrm{cm}^{-1}$ and $\mathrm{OH}$ stretching vibrations at $3407 ; 3408$ and 3409 $\mathrm{cm}^{-1}$. The weak bands 2648; 2646 and $2651 \mathrm{~cm}^{-1}$ may be assigned to organic impurities. The calculated U-O bond length $1.83 \AA$ corresponds to short U-O bonds in uranophane. The accessory admixtures of uranophane coatings are (meta)zeunerite and zálesíte. (Meta)zeunerite occasionally forms thin coatings of light green to emerald green tabular crystals (up tu $0.5 \mathrm{~mm}$ ) on the surface of the rocks. Chemical analyses of (meta)zeunerite correspond to the empirical formula $\left(\mathrm{Cu}_{0.66} \mathrm{~K}_{0.03} \mathrm{Fe}_{0.01} \mathrm{Ca}_{0.01}\right)_{\Sigma 0.71}\left(\mathrm{UO}_{2}\right)_{2.11}\left[\left(\mathrm{AsO}_{4}\right)_{1.96}\left(\mathrm{PO}_{4}\right)_{0.01}\right]_{\Sigma 1.97} \cdot 12 \mathrm{H}_{2} \mathrm{O}$. Zálesíite occurs as crystalline aggregates, nests, formed by tiny acicular crystals, up to $100 \mu \mathrm{m}$ in length. This is the second finding (occurrence) of this mineral in Slovakia. An average zálesíte chemical composition is $\left(\mathrm{Ca}_{0.83} \mathrm{REE}_{0.18} \mathrm{U}_{0.05} \mathrm{Al}_{0.03} \mathrm{Ti}_{0.01}\right)_{\Sigma 1.10}\left(\mathrm{Cu}_{5.81} \mathrm{Fe}_{0.06} \mathrm{Zn}_{0.02}\right)_{\Sigma 5.90}\left[\left(\mathrm{AsO}_{4}\right)_{2.75}\right.$ $\left.\left(\mathrm{SiO}_{4}\right)_{0.21}\left(\mathrm{PO}_{4}\right)_{0.02}\left(\mathrm{SO}_{4}\right)_{0.03}\right]_{\Sigma 3.01}(\mathrm{OH})_{5.10} \cdot 3 \mathrm{H}_{2} \mathrm{O}$. Malachite, which has been also found in the association, is only a minor mineral in the studied locality. The formation of uranyl silicates (uranophane) and minerals of the mixite group (zálesiite), present at the studied locality, points to neutralization of acidic supergene fluids in the mine dumps. Possibly, this environment later (precipitation of baryte) passed to neutral or slightly basic conditions (precipitation of carbonates - malachite). The identified uranyl phosphates/arsenates (zeunerite/metazeunerite), typical of an acidic environment, are therefore rare.
\end{abstract}

Key words: uranium, supergene zone, (meta)zeunerite, uranophane, malachite, zálesíte, Nižný Chmelienec, Nízke Tatry Mts., Western Carpathians

Obdrženo 1. 2. 2021; prijiato 3. 5. 2021

\section{Úvod}

Supergénne U minerály boli na Slovensku systematickejšie skúmané najmä v rámci gemerika, hronika, menej v tatriku, severnom veporiku či neogénnych vulkanitoch (Rojkovič 1997; Ferenc 2002, 2018; Števko et al. 2012; Kopáčik, Ferenc 2017; Ferenc et al. 2003, 2017, 2018, 2019; Polák et al. 2017; Števko et al. 2018; Hoppanová 2020). Z hl'adiska geologického prieskumu a t’ažobných prác zameraných na U rudy, bolo územie hronika (po gemeriku) druhým najviac preskúmaným územím

Slovenska (Tulis, Novotný 1998). Problematike zvetrávania U-Cu rúd v oblasti severných svahov Nízkych Tatier (prieskumná oblast' Čierny Váh, konkrétne rudný výskyt Východná-Nižný Chmelienec) sa v minulosti okrajovo venovali Drnzík (1969) a Rojkovič $(1997,1998)$. Predložený príspevok je venovaný charakteristike supergénnych minerálov prirodzene vznikajúcich vo zvyšku rudnej haldy na vyššie uvedenej lokalite, na základe mineralogického výskumu Hoppanovej (2020). 


\section{Lokalizácia, geologické a mineralogické pomery študovanej lokality}

Uránovo-medené (d’alej U-Cu) zrudnenie Nižný Chmelienec sa nachádza na severných svahoch západnej časti Nízkych Tatier (Král'ovohol'ské Nízke Tatry). Leží $\checkmark$ dne doliny Nižný Chmelienec približne $2.5 \mathrm{~km}$ na J od jej ústia do doliny Čierneho Váhu, $23 \mathrm{~km}$ na JV od okresného mesta Liptovský Mikuláš, 8 km smerom na J od Východnej (obr. 1). Geografické koordináty rudného výskytu sú $48.987^{\circ} \mathrm{N}, 19.900^{\circ} \mathrm{E}$.
Zistená produktívna poloha $v$ Nižnom Chmelienci bola najskôr overená povrchovými vrtnými prácami v 60 . rokoch 20. storočia. $\vee$ roku 1965 začal prieskum lokality banskými dielami (štôlne č. 31 a 32), doplnený podzemnými malopriemerovými vrtmi. Výsledky prieskumu však neboli uspokojivé, $v$ dôsledku čoho boli prieskumné aktivity na tejto lokalite v roku 1966 ukončené (Tulis, Novotný 1998).

Začiatkom 60. rokov 20. storočia boli na severných svahoch Nízkych Tatier realizované i d'alšie prie-

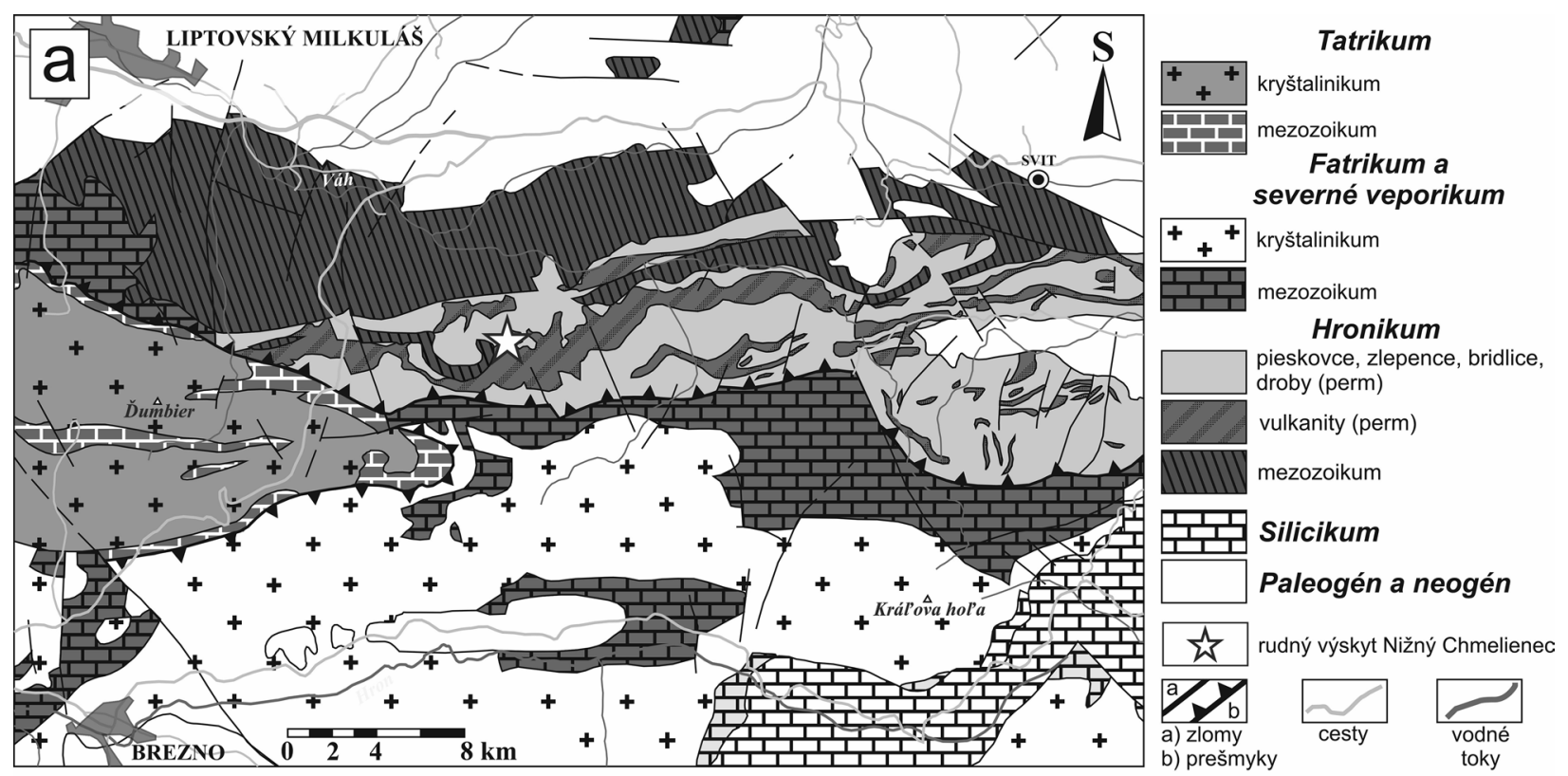

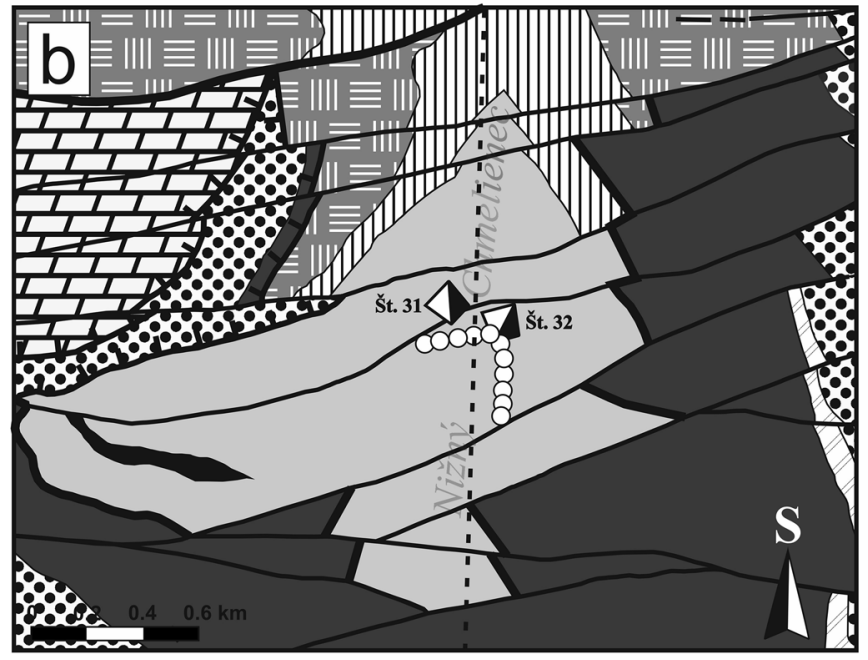

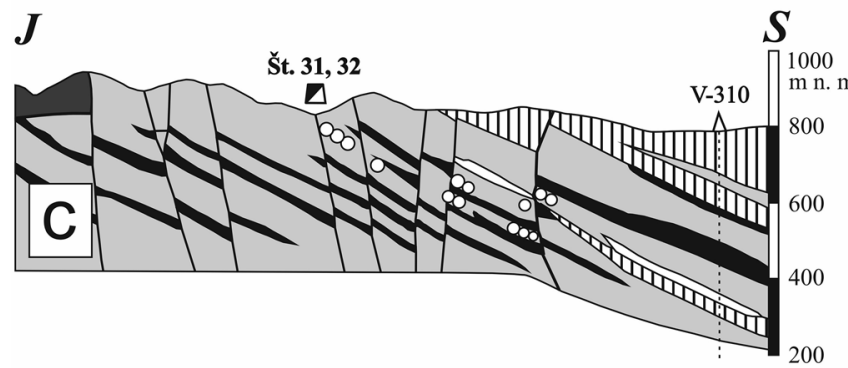

다담

Vrchný
dolomity, vápence

Vrchný a stredný trias

Spodný trias

Benkovské vrstvy

kremence, bridlice

Paleozoikum - vrchný perm

Malužinské súvrstvie - Brezovské vrstvy ilovité bridlice, aleurolity, pieskovce

Čiernovážsky vulkanogénny komplex

melafýry, porfyrity, kremenné porfyrity, diabázy

dioritové porfyrity, augitické a kremenné dioritové porfyrity

Kravanské vrstvy

- IIIII arkózové pieskovce, arkózy, aleurolity, ilovité bridlice,

000 polohy s U-Cu mineralizáciou

Kubašské vrstvy

[IIIIII polymiktné zlepence, arkózy a droby,

emnozrnité psamity a aleurolity

Červenecké vrstvy

Paleozoikum - spodný perm

aleurolity, ilovité bridlice, pieskovce, arkózové

pieskovce

sadrovec, anhydrit (vo vrchnej časti)

$\begin{array}{ll}\text { a } & \text { a) poklesové, prešmykové linie } \\ \text { b) násunové línie }\end{array}$

$\therefore$ línia rezu $\triangle$ vit $\triangle$ stôlña

Obr.1 a) Geologická stavba sv. časti Nízkych Tatier a Kozích chrbtov s vyznačením rudného výskytu Východná-Nižný Chmelienec (podla: Biely et al. 1992). b) Oblast' študovaného výskytu zobrazená v detailnej geologickej mape (podl'a Badár, Novotný 1970 in Tulis, Novotný 1998). c) Geologický profil rudného výskytu (podla Badár, Novotný 1970 in Tulis, Novotný 1998). 
skumné práce (kutacie ryhy a povrchové vrty) doplnené mineralogickým výskumom. Okrem najperspektívnejšej lokality Východná-Nižný Chmelienec, tu boli zistené aj iné výskyty U-Cu mineralizácie: Svarín, Ipoltica a Benkovský potok. Rudné polohy so stratiformnou U-Cu mineralizáciou sú situované vo vrchnej časti červeneckých vrstiev malužinského súvrstvia ipoltickej skupiny hronika (Drnzík 1969; Vozárová, Vozár 1988; Tulis, Novotný 1998). Plošný rozsah rudných polôh je malý. Na lokalitách Ipoltica a Svarín dosahujú dížku sotva $50 \mathrm{~m}$, na lokalite Benkovský potok sú zaznamenané tri polohy s dížkou do 200 $\mathrm{m}$. Morfológia rudných telies je šošovkovitá a vrstevnatá s premenlivou vel'kost'ou (dížka do $10 \mathrm{~m}$, hrúbka do $1 \mathrm{~m}$ ). Zvýšené obsahy U (0.01\% Ipoltica; max. $0.45 \%$ Benkovský potok) sú sprevádzané zvýšeným obsahom organického uhlíka (0.11 - $0.51 \%), \mathrm{Cu}(0.05-0.25 \%), \mathrm{Pb}$ a Co (Tulis, Novotný 1998).

Lokalita Nižný Chmelienec sa nachádza v relatívne komplikovanej tektonickej pozícii (výrazná zlomová zóna; tzv. zóna čiernovážskeho zlomu), vd’aka čomu boli polohy s U-Cu mineralizáciou postihnuté priečnou i pozdížnou tektonikou. Tektonická zóna je poklesového charakteru a má tri smery čiastkových štruktúr: I.) zlomy smeru SV - JZ pod uhlom približne $40^{\circ} \mathrm{s}$ úklonom $\mathrm{k} \mathrm{JV}$, pri amplitúdach poklesu 20 až $30 \mathrm{~m}$; II.) ojedinelé zlomy smeru SZ - JV, s azimutom zhruba $310^{\circ}$ so sklonom na JZ, s amplitúdou poklesávania blokov 10 až $15 \mathrm{~m}$; a III.) najmladšie zlomy smeru SSV - JJZ so sklonom prevažne na Z, zriedkavo i na V, s amplitúdami zdvihov približne $10 \mathrm{~m}$. Okrem uvedených zlomov boli pozorované i medzivrstevnaté zlomy (Veselý, Badár 1984; Rojkovič 1995; Tulis, Novotný 1998). Zlomová tektonika v priestore Nižného Chmelienca je výlučne porudná, bez známok hydrotermálnej mineralizácie.

Primárna U mineralizácia sa nachádza v najvrchnejšej časti spodnopermskej sekvencie, ktorú reprezentujú červenecké vrstvy malužinského súvrstvia hronika (Drnzík 1969; Vozárová, Vozár 1988; Tulis, Novotný 1998). Litologickú náplň červeneckých vrstiev tvoria hnedočervené arkózy, aleurolity a drobové pieskovce, pričom U-Cu mineralizácia je koncentrovaná najmä v sivých až sivozelených jemno- až strednozrnných arkózových pieskovcoch, typu tzv. med'natých pieskovcov (Drnzík 1969). Rudonosný horizont má hrúbku približne $50 \mathrm{~m}$, pričom rudné šošovky sú v ňom vertikálne i laterálne nepravideIne a sporadicky rozptýlené (Drnzík 1969; Novotný, Badár 1971; Veselý, Badár 1984; Rojkovič 1997; Tulis, Novotný 1998). Podla Rojkoviča (1997) sa obsah U v nich pohybuje od 0.03 do $0.5 \%$ (priemerne $0.06 \%$ ), maximálny zistený obsah $\mathrm{Cu}$ bol $0.16 \%$ (priemerne $0.07 \%$ ), mierne vyšší je obsah $\mathrm{Pb}(0.02 \%)$ a Co $(0.02 \%)$. Z rudného výskytu Nižný Chmelienec bolo celkovo vyt’ažených 89 kg kovového uránu (Tulis, Novotný 1998; Daniel 1999). Obsah organického uhlíka sa pohybuje okolo 0.2 \% (Drnzík 1969; Rojkovič 1998), mikroskopicky ani makroskopicky tu neboli zistené žiadne zuhol'natené fragmenty flóry.
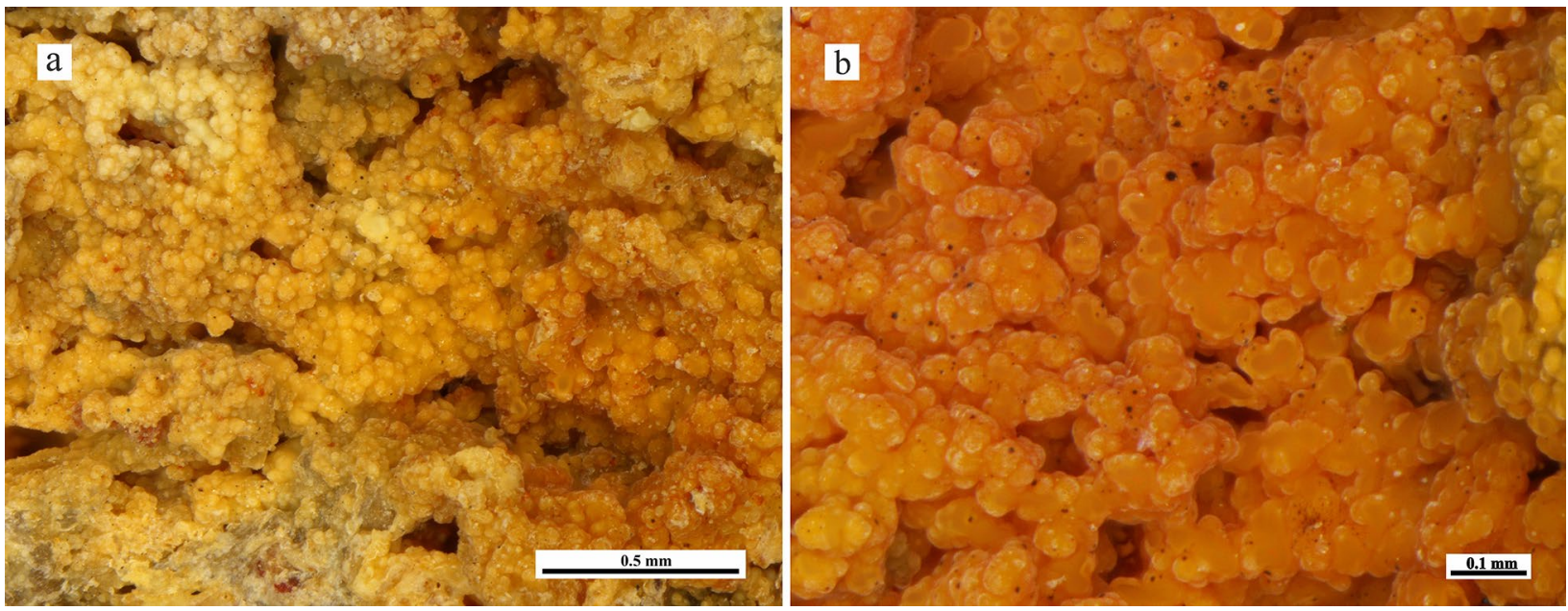

Obr. 2 a-b) Kôry l’advinovitých agregátov uranofánu z Nižného Chmelienca v rôznych odtieňoch žltej a oranžovej farby. Foto: E. Hoppanová.
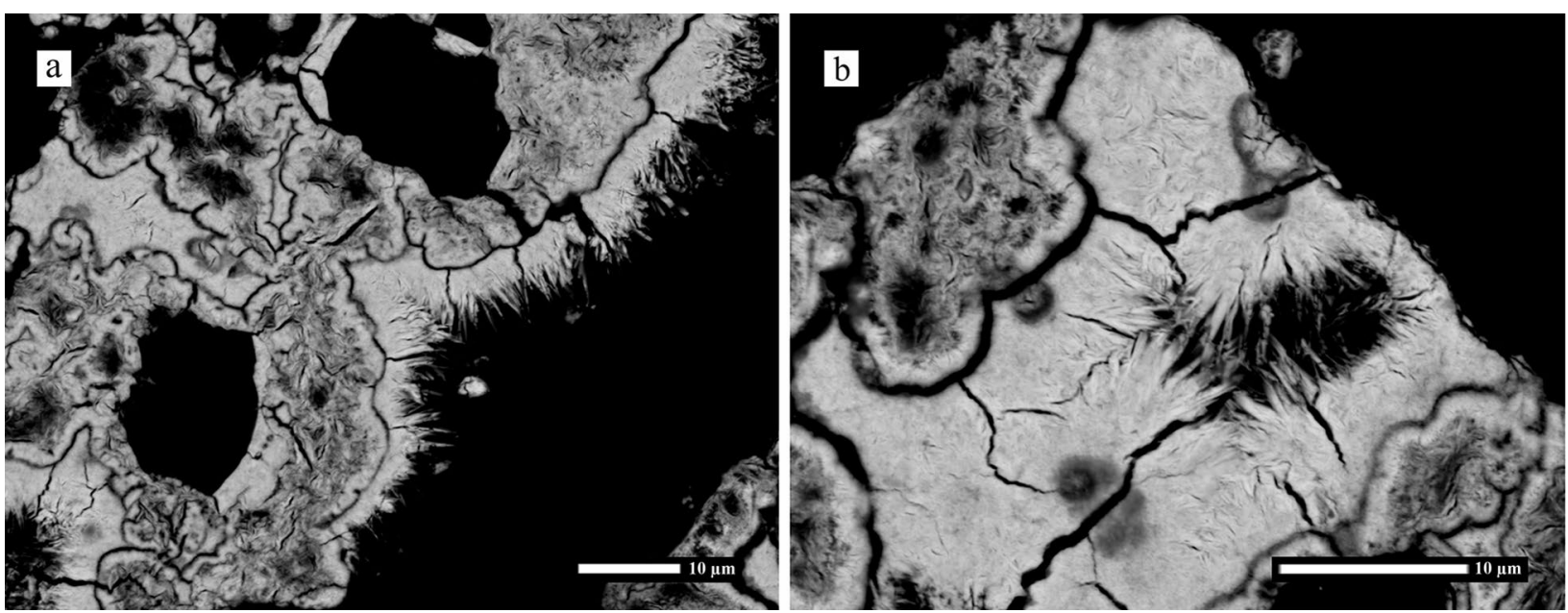

Obr. 3 a-b) Agregáty uranofánu zložené z typických ihlicovitých až vláknitých kryštálov. BSE foto: T. Mikuš. 
V zrudnených polohách hornín sú prítomné i kremenno -karbonátové žilky. Uránová mineralizácia spolu s $\mathrm{Cu}-\mathrm{Pb}$ mineralizáciou je prítomná najmä v tmele pieskovca. Uránové minerály vytvárajú kolomorfné agregáty koncentrované do tenkých vrstvičiek, ktoré sú prerastané mladšími minerálmi medi (najmä chalkopyritom). Rojkovič (1998) rozlišuje v Nižnom Chmelienci (resp. na SV Nízkych Tatier) dve generácie uránovej mineralizácie. Staršia, chudobnejšia uránová mineralizácia, reprezentovaná hlavne U-Ti oxidmi, má zretel'ný vrstvovitý charakter. Pretínaná je mladšou, bohatšou uraninitovou, respektíve U-Cu mineralizáciou kumulovanou $v$ zhlukoch a žilkách (aj karbonátových). Primárnu rudnú výplň tvorí: uraninit, pyrit, chalkopyrit, pyrotit, barit, galenit, tetraedrit, hematit, bornit, chlority a U-Ti oxidy. Supergénnu zónu charakterizuje asociácia minerálov: chalkozín, digenit, covellit, autunit (?), torbernit (?), azurit, malachit, goethit, dolomit a limonit (Drnzík 1969; Rojkovič 1995, 1997, 1998; Tulis, Novotný 1998).

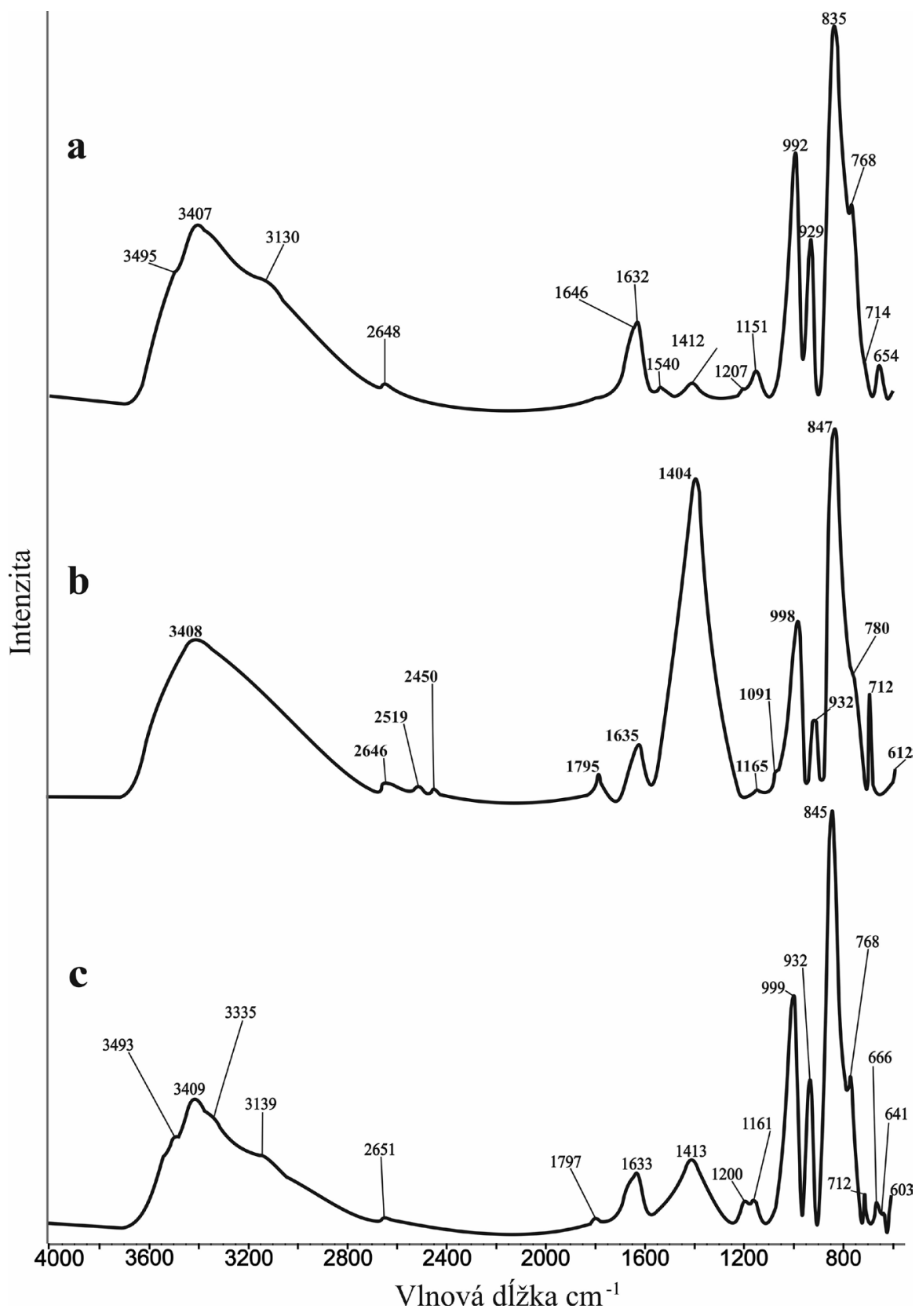

Obr. 4 a-c) Infračervené spektrá uranofánu z Nižného Chmelienca. Rozsah vInovej dížky 4000-600 $\mathrm{cm}^{-1}$ : a) žltý, b) oranžový a c) sýtožltý uranofán.

\section{Metodika výskumu}

Vzorkový materiál bol odobraný pomocou scintilačného rádiometra SGR, pri meracom rozsahu 350 - 3000 $\mathrm{KeV}$ a frekvencii merania $0.2 \mathrm{~s}$. Rádioaktivita vzoriek bola meraná v impulzoch za sekundu (cps).

Supergénne minerály boli študované pomocou binokulárnej lupy Nikon SMZ-1500 v spojení s digitálnou kamerou typu SD-Fi2 (Univerzita Mateja Bela, Banská Bystrica); lupa bola použitá aj pri detailnej separácii monominerálnych fáz pre IR meranie (infračervené spektroskopické štúdium) a pre vyhotovenie nábrusov.

Spektroskopická analýza $\mathrm{v}$ infračervenom spektre (spektrálny rozsah 4000 až $400 \mathrm{~cm}^{-1}$ ) bola realizovaná na prístroji Nicolet iS50 (Univerzita Mateja Bela, Banská Bystrica), za použitia konvenčnej techniky zoslabenej úpInej refrakcie (ATR) so syntetickým diamantom ako meracím kryštálom. Pri každom meraní bolo uskutočnených 32 skenov s krokom $4 \mathrm{~cm}^{-1}$. Zistené infračervené spektrá boli porovnané s viacerými internetovými databázami (RRUFF; lisa.chem.ut.ee) a zahraničnými prácami.

Chemické zloženie jednotlivých minerálov bolo kvantitatívne študované pomocou elektrónového mikroanalyzátora Jeol-JXA-8530F (Ústav vied o Zemi SAV, Banská Bystrica). Mikroanalyzátor bol využitý okrem bodových vlnovodisperzných mikroanalýz (WDS) aj pre účely fotodokumentácie $v$ spätne rozptýlených elektrónoch (BSE) a neštandardizované (orientačné) analýzy (EDS). WDS mikroanalýzy sa robili za nasledujúcich podmienok: urýchl'ovacie napätie $15 \mathrm{kV}$, merací prúd $15 \mathrm{nA}$ a priemer elektrónového lúča $10 \mu \mathrm{m}$. Detekčné limity sú uvádzané $v$ ppm, aplikovaná bola korekcia ZAF. Použité prírodné/syntetické štandardy a ich sprektrálne čiary boli: $\mathrm{Ca}$ $\left(K_{\alpha}\right.$ PETL, 37-70) - diopsid, $K$ $\left(K_{\alpha}^{\alpha}, P E T L, 45-50\right)$ - ortoklas, $U$ $\left(\mathrm{M}_{\beta}\right.$, PETL, 103-116) - UO $\mathrm{U}_{2}$ Th $\left(\mathrm{M}_{\alpha}, \mathrm{PETL}, 75-79\right)$ - thorianit, $\mathrm{Pb}$ (M ${ }_{\beta}$, PETL, 126-173) - krokoit, $S\left(K_{\alpha}, P E T L, 46-53\right)$ - baryt, $P$ $\left(K_{\alpha}, P E T L, 68-89\right)$ - apatit, $Y$ $\left(L_{\alpha}, P E T L, 131-166\right)-Y^{\prime} O_{4}, F$ $\left(K_{\alpha}, L D E 1,159-334\right)$ - fluorit, $\mathrm{Na}$ $\left(K_{\alpha}, T A P, 68-126\right)$ - albit, $\operatorname{Sr}\left(L_{\alpha}\right.$, TAP, 120-269) - celestín, Si (K $\mathrm{K}_{\alpha^{\prime}}$, TAP, 82-95) - ortoklas, Al ( $\mathrm{K}_{\mathrm{a}}$, TAP, 52-60) albit, As ( $L_{\alpha}$, TAP, 133-257) - GaAs, Mg (K $\mathrm{K}_{\alpha}$, TAP, 48-101) - diopsid, Lu ( $\mathrm{L}_{\alpha}, \mathrm{LIFH}$, 204-210) - LuPO $_{4}$, Ho ( $L_{\beta}$, LIFH, 355-365) - $\mathrm{HoPO}_{4}, \mathrm{Yb}\left(\mathrm{L}_{\alpha}, \mathrm{LIFH}\right.$, 186-189) - $\mathrm{YbPO}_{4}, \operatorname{Tm}\left(\mathrm{L}_{\alpha}, \mathrm{LIFH}\right.$, 175-183) - $\mathrm{TmPO}_{4}, \mathrm{Er}\left(\mathrm{L}_{\alpha}\right.$, LIFH, 173-176) - $\mathrm{ErPO}_{4}, \mathrm{Gd}\left(\mathrm{L}_{\beta}, \mathrm{LIFH}\right.$, 283-293) - $\mathrm{GdPO}_{4}$, Dy $\left(\mathrm{L}_{\alpha}\right.$, LIFH, 
148-153) - DyPO, Tb (L $\left(\mathrm{L}_{\beta}\right.$, LIFH, 251-269) - $\mathrm{SmPO}_{4}$, Eu ( $\left.\mathrm{L}_{\alpha}, \mathrm{LIFH}, 130-135\right)$ $E_{4 P O}, \operatorname{Pr}\left(L_{\beta}, \mathrm{LIFH}, 230-242\right)-\mathrm{PrPO}_{4}, \mathrm{Nd}\left(\mathrm{L}_{\alpha}\right.$, LIFH, 123127) $-\mathrm{NdPO}_{4}$, Ce $\left(\mathrm{L}_{\alpha}, \mathrm{LIFH}, 121-130\right)-\mathrm{CePO}_{4}$, La $\left(\mathrm{L}_{\alpha}\right.$, LIFH, 130-139) - $\mathrm{LaPO}_{4}$, Co (K, LIFH, 94-109) - Co, Zn $\left(K_{\alpha}\right.$, LIF, 308-372) - gahnit, Cu (Ko, LIF, 214-253) - kuprit, Fe $\left(K_{\alpha}\right.$, LIF, 225-297) - olivín, Ti (K $K_{\alpha}$ LIF, 211-247) - rutil, $\mathrm{Ba}\left(\mathrm{L}_{\alpha}\right.$, LIF, 546-864) - barit, Bi (M $\mathrm{M}_{\alpha}$, PETJ, 310-664) - $\mathrm{Bi}_{2}$ $\mathrm{Se}_{3}$. V tabul'kách uvádzaných $\mathrm{v}$ d'alšom texte nie sú zahrnuté prvky, ktorých hodnoty obsahu sú pod detekčným limitom.

\section{Výsledky}

\section{Supergénne minerály}

Uranofán bol identifikovaný IR spektroskopiou a WDS analýzami. Tvorí hlavnú súčast' žltých/žltozelených kryštalických kôrok na puklinách hornín, alebo vystupuje samostatne. Vytvára l'advinovité agregáty a nátekovité povlaky, alebo kôrky na plochách $(0.1 \times 0.5 \mathrm{~cm})$. Sfarbenie uranofánu je $v$ rôznych odtieňoch žltej, alebo oranžové-sýtooranžové (obr. $2 a, b)$. Jeho globulárne útvary pozostávajú z vejárovitých (resp. snopcovitých) agregátov

Tabul'ka 1 Výsledky infračerveného a Ramanovho spektra uranofánu

\begin{tabular}{|c|c|c|c|c|c|c|c|c|}
\hline $\begin{array}{c}\text { a } \\
\text { (táto práca) }\end{array}$ & $\begin{array}{c}\text { b } \\
\text { (táto práca) }\end{array}$ & $\begin{array}{c}\text { c } \\
\text { (táto práca) }\end{array}$ & $\begin{array}{c}\text { Frost et al. } \\
(2006 \text { a) }\end{array}$ & $\begin{array}{c}\text { Frost et al. } \\
(2006 \text { b) }\end{array}$ & $\begin{array}{l}\text { Frost et al. } \\
\text { (2006 b) }\end{array}$ & $\begin{array}{l}\text { Frost et al. } \\
\text { (2006 b) }\end{array}$ & $\begin{array}{l}\text { Frost et al. } \\
(2006 \mathrm{a})\end{array}$ & $\begin{array}{l}\text { Colmenero } \\
\text { et al. (2018) }\end{array}$ \\
\hline $\begin{array}{c}\text { Nižný } \\
\text { Chmelienec }\end{array}$ & $\begin{array}{c}\text { Nižný } \\
\text { Chmelienec }\end{array}$ & $\begin{array}{c}\text { Nižný } \\
\text { Chmelienec }\end{array}$ & $\begin{array}{l}\text { Shaba, } \\
\text { Kongo }\end{array}$ & $\begin{array}{l}\text { Shaba, } \\
\text { Kongo }\end{array}$ & $\begin{array}{c}\text { Poison } \\
\text { Canyon, } \\
\text { Nové Mexico }\end{array}$ & $\begin{array}{l}\text { Eagle Pass, } \\
\text { West Texas }\end{array}$ & $\begin{array}{l}\text { Shaba, } \\
\text { Kongo }\end{array}$ & \\
\hline IR & IR & IR & IR & IR & IR & IR & Raman & Raman \\
\hline $\begin{array}{c}\text { pozícia } \\
\left(\mathrm{cm}^{-1}\right)\end{array}$ & $\begin{array}{c}\text { pozícia } \\
\left(\mathrm{cm}^{-1}\right)\end{array}$ & $\begin{array}{c}\text { pozícia } \\
\left(\mathrm{cm}^{-1}\right)\end{array}$ & $\begin{array}{c}\text { pozícia } \\
\left(\mathrm{cm}^{-1}\right)\end{array}$ & $\begin{array}{c}\text { pozícia } \\
\left(\mathrm{cm}^{-1}\right)\end{array}$ & $\begin{array}{c}\text { pozícia } \\
\left(\mathrm{cm}^{-1}\right)\end{array}$ & $\begin{array}{c}\text { pozícia } \\
\left(\mathrm{cm}^{-1}\right)\end{array}$ & $\begin{array}{c}\text { pozícia } \\
\left(\mathrm{cm}^{-1}\right)\end{array}$ & $\begin{array}{c}\text { pozícia } \\
\left(\mathrm{cm}^{-1}\right)\end{array}$ \\
\hline- & - & - & - & 3749 & - & - & - & - \\
\hline- & - & - & - & - & 3696 & 3693.6 & - & - \\
\hline - & - & - & - & - & 3619 & 3614.3 & - & - \\
\hline- & - & - & 3546 & 3550 & 3581 & 3540 & - & - \\
\hline- & - & - & - & - & 3526 & - & - & - \\
\hline- & - & - & - & - & 3524 & - & - & - \\
\hline 3495 & - & 3493 & - & - & - & 3495 & 3492 & 3485 \\
\hline- & - & - & - & - & 3435 & 3424 & 3463 & 3478 \\
\hline 3407 & 3408 & 3409 & 3407 & 3409 & 3403 & - & - & - \\
\hline- & - & - & - & - & 3392 & - & - & - \\
\hline- & - & - & - & - & 3371 & 3365 & - & 3359 \\
\hline - & - & - & - & - & - & - & - & 3357 \\
\hline - & - & 3335 & - & - & - & 3332 & - & - \\
\hline- & - & - & - & - & - & - & - & 3295 \\
\hline - & - & - & - & - & - & - & - & 3272 \\
\hline - & - & - & - & - & - & - & - & 3238 \\
\hline - & - & - & - & - & - & 3225 & - & 3222 \\
\hline- & - & - & - & - & 3205 & - & 3215 & - \\
\hline- & - & - & 3177 & 3175 & - & - & - & - \\
\hline 3130 & - & 3139 & - & - & 3123 & 3135 & - & 3149 \\
\hline- & - & - & - & 2957 & 2956 & - & - & - \\
\hline- & - & - & 2920 & 2921 & 2922 & - & - & - \\
\hline- & - & - & 2918 & - & 2908 & 2913 & - & - \\
\hline- & - & - & - & 2893 & - & - & 2900 & - \\
\hline- & - & - & 2867 & 2869 & 2870 & - & - & - \\
\hline- & - & - & 2849 & 2851 & 2851 & - & - & - \\
\hline- & - & - & - & - & 2830 & - & - & - \\
\hline- & - & - & - & - & - & - & 2729 & - \\
\hline 2648 & 2646 & 26508 & - & - & - & - & - & - \\
\hline- & 2516 & - & - & - & - & - & - & - \\
\hline- & 2450 & - & - & - & - & - & 2477 & - \\
\hline- & - & - & - & 2235 & - & - & - & - \\
\hline- & - & - & - & - & - & - & 2137 & - \\
\hline- & 1795 & 1797 & - & - & - & - & - & - \\
\hline- & - & - & 1665 & 1665 & 1666 & 1668 & - & - \\
\hline 1646 & - & - & - & - & - & - & - & - \\
\hline 1633 & 1635 & 1633 & - & - & - & - & - & - \\
\hline- & - & - & 1624 & 1624 & 1625 & 1627 & - & - \\
\hline- & - & - & - & 1582 & 1567 & - & - & - \\
\hline- & - & - & 1558 & - & - & 15548 & - & - \\
\hline 1540 & - & - & - & 1539 & - & - & - & - \\
\hline
\end{tabular}


Tabul'ka 1 Výsledky infračerveného a Ramanovho spektra uranofánu - pokračovanie

\begin{tabular}{|c|c|c|c|c|c|c|c|c|}
\hline $\begin{array}{c}a \\
\text { (táto práca) }\end{array}$ & $\begin{array}{c}\mathrm{b} \\
\text { (táto práca) }\end{array}$ & $\begin{array}{c}\text { c } \\
\text { (táto práca) }\end{array}$ & $\begin{array}{c}\text { Frost et al. } \\
(2006 \text { a) }\end{array}$ & $\begin{array}{l}\text { Frost et al. } \\
(2006 \mathrm{~b})\end{array}$ & $\begin{array}{l}\text { Frost et al. } \\
(2006 \mathrm{~b})\end{array}$ & $\begin{array}{l}\text { Frost et al. } \\
(2006 \text { b) }\end{array}$ & $\begin{array}{c}\text { Frost et al. } \\
(2006 \text { a) }\end{array}$ & $\begin{array}{l}\text { Colmenero } \\
\text { et al. (2018) }\end{array}$ \\
\hline $\begin{array}{c}\text { Nižný } \\
\text { Chmelienec }\end{array}$ & $\begin{array}{c}\text { Nižný } \\
\text { Chmelienec }\end{array}$ & $\begin{array}{c}\text { Nižný } \\
\text { Chmelienec }\end{array}$ & $\begin{array}{l}\text { Shaba, } \\
\text { Kongo }\end{array}$ & $\begin{array}{l}\text { Shaba, } \\
\text { Kongo }\end{array}$ & $\begin{array}{c}\text { Poison } \\
\text { Canyon, } \\
\text { Nové Mexico }\end{array}$ & $\begin{array}{l}\text { Eagle Pass, } \\
\text { West Texas }\end{array}$ & $\begin{array}{l}\text { Shaba, } \\
\text { Kongo }\end{array}$ & \\
\hline IR & IR & IR & IR & IR & IR & IR & Raman & Raman \\
\hline $\begin{array}{c}\text { pozícia } \\
\left(\mathrm{cm}^{-1}\right)\end{array}$ & $\begin{array}{c}\text { pozícia } \\
\left(\mathrm{cm}^{-1}\right)\end{array}$ & $\begin{array}{c}\text { pozícia } \\
\left(\mathrm{cm}^{-1}\right)\end{array}$ & $\begin{array}{c}\text { pozícia } \\
\left(\mathrm{cm}^{-1}\right)\end{array}$ & $\begin{array}{c}\text { pozícia } \\
\left(\mathrm{cm}^{-1}\right)\end{array}$ & $\begin{array}{c}\text { pozícia } \\
\left(\mathrm{cm}^{-1}\right)\end{array}$ & $\begin{array}{c}\text { pozícia } \\
\left(\mathrm{cm}^{-1}\right)\end{array}$ & $\begin{array}{c}\text { pozícia } \\
\left(\mathrm{cm}^{-1}\right)\end{array}$ & $\begin{array}{c}\text { pozícia } \\
\left(\mathrm{cm}^{-1}\right)\end{array}$ \\
\hline- & - & - & 1530 & - & - & - & - & - \\
\hline- & - & - & - & 1462 & 1460 & - & - & - \\
\hline- & - & - & - & 1438 & 1430 & - & - & - \\
\hline 1412 & - & 1413 & 1420 & - & - & - & - & - \\
\hline- & 1404 & - & - & - & - & - & - & - \\
\hline- & - & - & - & - & 1377 & - & - & - \\
\hline- & - & - & 1323 & - & 1326 & - & - & - \\
\hline- & - & - & 1284 & 1292 & - & 1297 & - & - \\
\hline- & - & - & - & - & 1278 & - & - & - \\
\hline 1207 & - & 1200 & - & - & - & - & - & 1222 \\
\hline 1151 & - & 1161 & 1145 & 1145 & 1144 & 1146 & - & 1146 \\
\hline- & - & - & - & - & - & - & 1005 & - \\
\hline 992 & 998 & 999 & - & 996 & 990 & - & - & - \\
\hline- & - & - & 989 & 987 & - & 989 & - & - \\
\hline- & - & - & - & - & - & - & 964 & - \\
\hline- & - & - & - & - & - & - & 961 & 958 \\
\hline- & - & - & - & - & - & 945 & 950 & 942 \\
\hline 9230 & 932 & 932 & 932 & 931 & 936 & 923 & - & - \\
\hline- & - & - & 915 & 914 & 9167 & - & - & - \\
\hline- & - & - & - & - & 878 & 880 & 886 & 884 \\
\hline- & - & - & - & 856 & - & 852 & - & 857 \\
\hline 835 & 847 & 846 & 833 & 838 & 841 & 836 & 839 & 837 \\
\hline- & - & - & 827 & 825 & 829 & 829 & - & 813 \\
\hline- & - & - & - & 800 & 796 & - & 797 & 804 \\
\hline- & - & - & 792 & - & - & - & 793 & - \\
\hline- & 780 & - & - & - & - & 786 & - & 776 \\
\hline 768 & - & 768 & 767 & - & 766 & 766 & - & 766 \\
\hline- & - & - & - & 764 & - & 763 & - & 760 \\
\hline- & - & - & 740 & 758 & 758 & - & - & - \\
\hline- & - & - & - & - & 733 & - & - & - \\
\hline 714 & 712 & 712 & - & - & - & - & 711 & 717 \\
\hline- & - & - & - & - & - & 697 & - & 686 \\
\hline 654 & - & 666 & 653 & 653 & 659 & 655 & - & - \\
\hline- & 613 & 603 & - & - & - & - & - & 618 \\
\hline
\end{tabular}
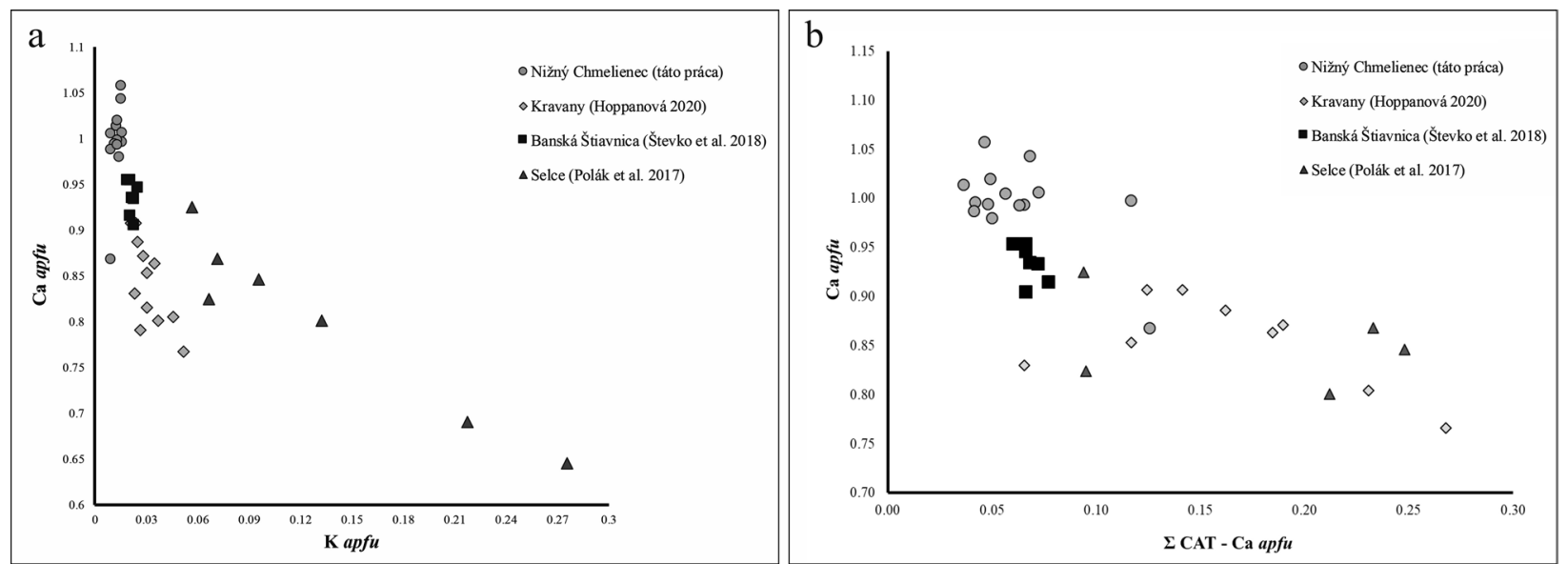

Obr. 5 a) Závislost' obsahov prvkov v katiónovej pozícii v uranofánoch zo Slovenska. a) Závislost' obsahu Ca vs. K (apfu). b) Závislost' obsahu Ca vs. ostatné prvky (apfu). 
jemných ihlicovitých až vláknitých kryštálov s dížkou okolo $20 \mu \mathrm{m}$ (obr. 3a, b). Vystupuje v paragenetickej asociácii so vzácnejším baritom, zálesíitom a (meta)zeuneritom.

Infračervené spektrá uranofánu z Nižného Chmelienca (obr. 4a - c) mali vzhl'adom na menšie množstvo materiálu a tesnú asociáciu $s$ inými minerálnymi fázami (nedokonalá separácia) mierne odchýlky v porovnaní s publikovanými spektrami v prácach Čejka, Urbanec (1990), Čejka (in Burns, Finch 1999) a Frost et al. (2006 a, b). Porovnanie výsledkov IR analýz s údajmi vybraných prác prehl'adne uvádza tabul'ka 1. Najintenzívnejší pás na pozíciách oblasti $850-760 \mathrm{~cm}^{-1}$ je v zmysle prác Frost et al. (2006 a, b) a Čejka (in Burns, Finch 1999) pridelený valenčným vibráciám $v_{3}\left(\mathrm{UO}_{2}\right)^{2+}$. Z vinovej dížky týchto pásov $\left(835 \mathrm{~cm}^{-1}, 847 \mathrm{~cm}^{-1}, 845 \mathrm{~cm}^{-1}\right)$ bola na základe vzt'ahu publikovaného v práci Bartletta a Cooneyho (1989) vypočítaná dížka väzby U-O v uranyle: $1.83 \AA$, ktorá korešpon- duje s publikovanými údajmi (1.80 Å). Je v dobrej zhode i s údajmi uranofánu zo Seliec (hodnota pásu: $835 \mathrm{~cm}^{-1}$; hodnota U-O v uranyle: 1.82 Å; Polák et al. 2016). Pásy vo vlnovej dížke 1000 až $900 \mathrm{~cm}^{-1}$ sú náznakom prítomnosti antisymetrických valenčných vibrácii $v_{3}\left(\mathrm{SiO}_{4}\right)^{4-}($ Čejka in Burns, Finch 1999; Frost et al. 2006 a, b). V infračervených spektrách uranofánu možno pozorovat' i pásy na pozíciách 1150 - $1199 \mathrm{~cm}^{-1}$, ktoré súvisia so symetrickou valenčnou vibráciou $v_{1}\left(\mathrm{SiO}_{4}\right)^{4-}$ (Chernorukov, Kortikov 2002). Ako vo svojej práci uvádza Čejka (in Burns, Finch 1999), pásy na pozíciách $600-560 \mathrm{~cm}^{-1}$ dokumentujú symetrické ohýbanie $\left(\mathrm{SiO}_{4}\right)^{4-}$. Výsledky infračerveného spektra uranofánu z Nižného Chmelienca pozitívne korelujú s týmto údajom. Prítomnost' vody (napínanie valenčnej vibrácie $\mathrm{O}-\mathrm{H}$ väzby) v uranofáne charakterizujú pásy v oblasti $3550-3100 \mathrm{~cm}^{-1}$. Najintenzívnejšie pásy tejto oblasti $\left(3407 \mathrm{~cm}^{-1}, 3408 \mathrm{~cm}^{-1}, 3409 \mathrm{~cm}^{-1}\right)$ študované-

Tabul'ka 2 Chemické zloženie uranofánu z rudného výskytu Východná - Nižný Chmelienec

\begin{tabular}{|c|c|c|c|c|c|c|c|c|c|c|c|c|c|c|}
\hline & 1 & 2 & 3 & 4 & 5 & 6 & 7 & 8 & 9 & 10 & 11 & 12 & 13 & 14 \\
\hline $\mathrm{K}_{2} \mathrm{O}$ & 0.16 & 0.10 & 0.15 & 0.14 & 0.17 & 0.14 & 0.16 & 0.15 & 0.18 & 0.11 & 0.15 & 0.13 & 0.11 & 0.15 \\
\hline $\mathrm{MgO}$ & 0.08 & 0.29 & 0.04 & 0.08 & 0.04 & 0.07 & 0.02 & 0.05 & 0.07 & 0.01 & 0.08 & 0.06 & 0.01 & 0.08 \\
\hline $\mathrm{aO}$ & 6.59 & 5.50 & 6.55 & 6.64 & 6.64 & 5.81 & 6.71 & 6.70 & 6.67 & 6.69 & 6.67 & 6.74 & 6.59 & 6.64 \\
\hline $\mathrm{aO}$ & 0.00 & 0.15 & 0.03 & 0.00 & 0.25 & & 0.27 & 0.00 & & & 0.02 & 0.25 & 0.00 & 0.20 \\
\hline $\mathrm{eO}$ & 0.06 & 0.09 & 0.00 & 0.05 & 0.09 & 0.04 & 0.01 & 0.12 & 0.04 & 0.20 & 0.64 & 0.23 & 0.14 & 0.07 \\
\hline $\mathrm{UO}_{3}$ & 71.23 & 66.76 & 70.12 & 70.47 & 70.66 & 58.46 & 71.16 & 70.00 & 70.63 & 70.55 & 68.01 & 71.72 & 70.71 & 70.73 \\
\hline $\mathrm{SiO}_{2}$ & 13.47 & 12.96 & 13.00 & 12.86 & 12.68 & 10.77 & 11.32 & 12.89 & 13.49 & 13.21 & 13.48 & 13.55 & 13.49 & 13.30 \\
\hline $\mathrm{H}_{2} \mathrm{O}^{*}$ & 11.76 & 11.78 & 11.72 & 11.65 & 11.66 & 11.81 & 11.33 & 11.73 & 11.79 & 11.74 & 12.04 & 11.76 & 11.76 & 11.75 \\
\hline $\mathrm{hm} 0$ & 103.35 & 97.63 & 10161 & 101.89 & 102.19 & 87.29 & 100.98 & 101.64 & 102.87 & 102.64 & 101.09 & 104.44 & 10281 & 102.92 \\
\hline \multicolumn{15}{|c|}{ atómové koeficienty } \\
\hline & & 01 & & & 02 & 0.02 & 0.02 & 0.01 & & & 01 & & & 0.01 \\
\hline $\mathrm{Mg}^{2+}$ & 02 & 0.06 & 0.01 & 0.02 & 0.01 & 0.02 & 0.00 & 01 & 0.01 & 0.00 & 0.02 & .01 & .00 & 0.02 \\
\hline $\mathrm{Ca}^{2+}$ & & 0.87 & & 1.01 & 1.01 & 1.04 & 1.06 & 02 & 00 & .01 & 1.00 & .99 & .99 & 0.99 \\
\hline$a^{2+}$ & 0.00 & 0.01 & 0.00 & 0.00 & 0.01 & 0.01 & 0.02 & 0.00 & 0.00 & 0.01 & 0.00 & 0.01 & 0.00 & 0.01 \\
\hline & & 0.01 & & & & 0.01 & 0.00 & & 0.00 & & 0.07 & & .02 & 0.01 \\
\hline $\mathrm{U}^{6+}$ & 2.08 & 2.07 & 2.09 & 2.11 & 2.10 & 2.06 & 2.20 & 2.09 & 2.07 & 2.08 & 2.00 & 2.07 & 2.08 & 2.07 \\
\hline$\Sigma$ CAT & .02 & 0.96 & 1.01 & 1.05 & 1.06 & 1.10 & 1.10 & 1.05 & 1.03 & 1.05 & 1.10 & 1.05 & 1.02 & 1.04 \\
\hline & & & & 1.83 & & 1.80 & 1.66 & 1.83 & 1.88 & 1.85 & 1.88 & 1.86 & 1.89 & 1.86 \\
\hline $\mathrm{OH}^{*}$ & 0.59 & 0.36 & 0.76 & 0.80 & 0.95 & 0.87 & 1.61 & 0.79 & 0.53 & 0.71 & 0.55 & 0.66 & 0.52 & 0.65 \\
\hline
\end{tabular}

Normalizované na 5 atómov. Obsah $\mathrm{H}_{2} \mathrm{O}$ dopočítaný na základe ideálneho vzorca uranofánu a nábojovej bilancie.

Obr. 6 Detailný pohlad na kryštalické povlaky (meta)zeuneritu. Foto: E. Hoppanová.

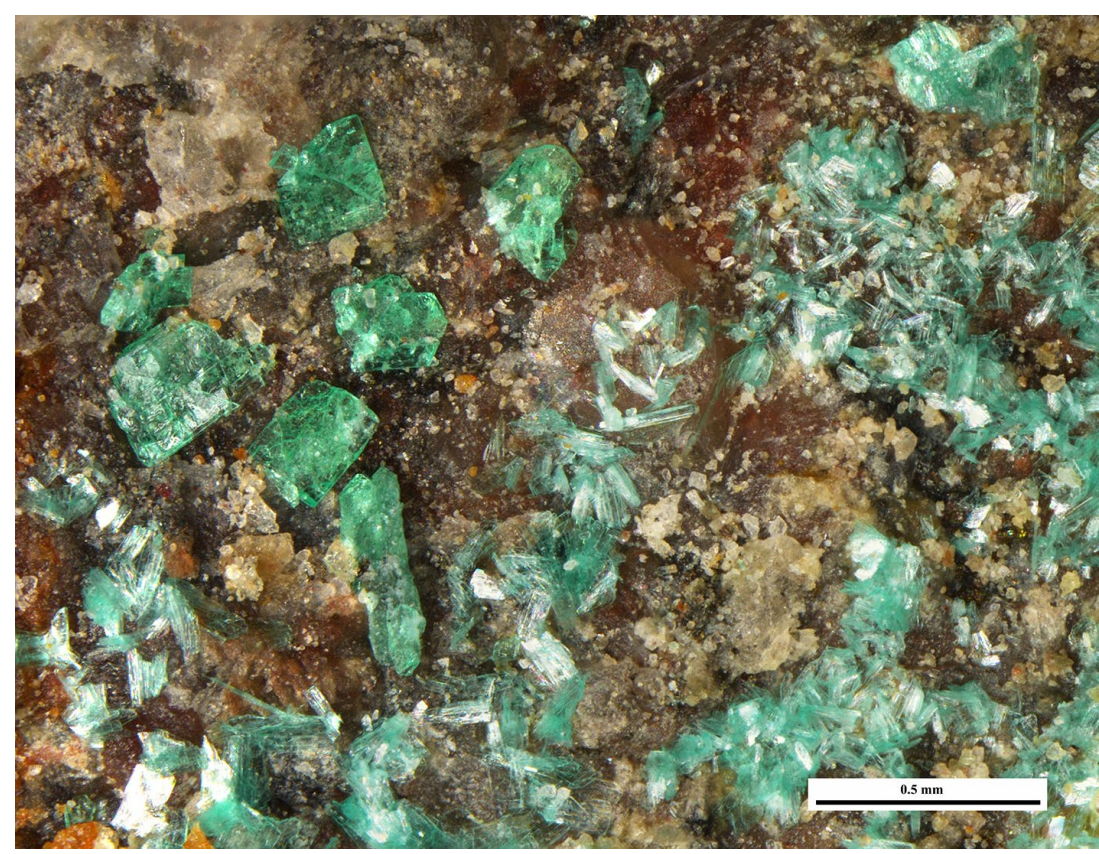


Tabul'ka 3 Mikroanalýzy (meta)zeuneritu z lokality Východná - Nižný Chmelienec

\begin{tabular}{lccccc}
\hline & 1 & 2 & 3 & 4 & 5 \\
\hline $\mathrm{K}_{2} \mathrm{O}$ & 0.13 & 0.12 & 0.11 & 0.19 & 0.11 \\
$\mathrm{CaO}$ & 0.04 & 0.04 & 0.05 & 0.23 & 0.01 \\
$\mathrm{BaO}$ & 0.00 & 0.13 & 0.17 & 0.00 & 0.00 \\
$\mathrm{FeO}$ & 0.07 & 0.06 & 0.12 & 0.13 & 0.18 \\
$\mathrm{CoO}$ & 0.04 & 0.05 & 0.00 & 0.02 & 0.05 \\
$\mathrm{CuO}$ & 6.19 & 5.80 & 4.65 & 6.13 & 5.59 \\
$\mathrm{ZnO}$ & 0.00 & 0.05 & 0.05 & 0.04 & 0.00 \\
$\mathrm{TiO}_{2}$ & 0.09 & 0.01 & 0.00 & 0.00 & 0.03 \\
$\mathrm{UO}_{3}$ & 64.71 & 65.28 & 65.25 & 65.36 & 64.62 \\
$\mathrm{P}_{2} \mathrm{O}_{5}$ & 0.11 & 0.07 & 0.06 & 0.04 & 0.06 \\
$\mathrm{As}_{2} \mathrm{O}_{5}$ & 24.45 & 23.34 & 23.64 & 24.10 & 25.56 \\
$\mathrm{SO}_{3}$ & 0.01 & 0.02 & 0.04 & 0.01 & 0.00 \\
$\mathrm{H}_{2} \mathrm{O}^{*}$ & 24.13 & 23.46 & 23.33 & 23.88 & 24.40 \\
\hline $\mathrm{\Sigma}$ & 119.97 & 118.43 & 117.47 & 120.13 & 120.61
\end{tabular}

\begin{tabular}{lllllll}
\hline$\Sigma$ hm. \% & 119.97 & 118.43 & 117.47 & 120.13 & 120.61
\end{tabular} atómové koeficienty

\begin{tabular}{llllll}
\hline $\mathrm{K}^{+}$ & 0.03 & 0.02 & 0.02 & 0.04 & 0.02 \\
$\mathrm{Ca}^{2+}$ & 0.01 & 0.01 & 0.01 & 0.04 & 0.00 \\
$\mathrm{Ba}^{2+}$ & 0.00 & 0.01 & 0.01 & 0.00 & 0.00 \\
$\mathrm{Fe}^{2+}$ & 0.01 & 0.01 & 0.02 & 0.02 & 0.02 \\
$\mathrm{Co}^{2+}$ & 0.01 & 0.01 & 0.00 & 0.00 & 0.01 \\
$\mathrm{Cu}^{2+}$ & 0.72 & 0.69 & 0.55 & 0.71 & 0.64 \\
$\mathrm{Zn}^{2+}$ & 0.00 & 0.01 & 0.01 & 0.00 & 0.00 \\
$\mathrm{Ti}^{4+}$ & 0.01 & 0.00 & 0.00 & 0.00 & 0.00 \\
$\mathrm{U}^{6+}$ & 2.09 & 2.15 & 2.16 & 2.11 & 2.07 \\
\hline$\Sigma \mathrm{CAT}$ & 2.86 & 2.90 & 2.78 & 2.92 & 2.76 \\
\hline $\mathrm{P}^{5+}$ & 0.01 & 0.01 & 0.01 & 0.01 & 0.01 \\
$\mathrm{As}^{5+}$ & 1.97 & 1.91 & 1.95 & 1.94 & 2.04 \\
$\mathrm{~S}^{6+}$ & 0.00 & 0.00 & 0.00 & 0.00 & 0.00 \\
\hline$\Sigma \mathrm{AN}$ & 1.98 & 1.93 & 1.96 & 1.95 & 2.04 \\
\hline $\mathrm{H}_{3} \mathrm{O}^{+}$ & 0.22 & 0.00 & 0.35 & 0.01 & 0.62 \\
\hline
\end{tabular}

Normalizované na 12 kyslíkov. Obsah $\mathrm{H}_{2} \mathrm{O}$ dopočítaný na základe ideálneho vzorca (meta)zeuneritu.
Tabul'ka 4 Chemické zloženie zálesiitu z lokality Východná Nižný Chmelienec

\begin{tabular}{lccccccc}
\hline & 1 & 2 & 3 & 4 & 5 & 6 & 7 \\
\hline $\mathrm{CaO}$ & 4.64 & 4.18 & 4.44 & 3.83 & 4.03 & 5.22 & 4.73 \\
$\mathrm{FeO}$ & 0.51 & 0.45 & 0.50 & 0.52 & 0.41 & 0.42 & 0.46 \\
$\mathrm{ZnO}$ & 0.21 & 0.22 & 0.20 & 0.22 & 0.24 & 0.12 & 0.06 \\
$\mathrm{PbO}$ & 0.05 & 0.01 & 0.00 & 0.06 & 0.14 & 0.10 & 0.01 \\
$\mathrm{UO}_{2}$ & 1.27 & 1.42 & 1.04 & 1.59 & 0.71 & 1.01 & 1.33 \\
$\mathrm{Al}_{2} \mathrm{O}_{3}$ & 0.19 & 0.14 & 0.08 & 0.41 & 0.85 & 0.28 & 0.09 \\
$\mathrm{TiO}_{2}$ & 0.00 & 0.03 & 0.13 & 0.20 & 0.00 & 0.05 & 0.08 \\
$\mathrm{Y}_{2} \mathrm{O}_{3}$ & 3.06 & 3.14 & 2.73 & 3.34 & 3.67 & 2.99 & 3.07 \\
$\mathrm{Nd}_{2} \mathrm{O}_{3}$ & 0.20 & 0.25 & 0.50 & 0.21 & 0.15 & 0.18 & 0.19 \\
$\mathrm{Dy}_{2} \mathrm{O}_{3}$ & 0.46 & 0.50 & 0.52 & 0.78 & 0.64 & 0.55 & 0.57 \\
$\mathrm{CuO}$ & 43.89 & 42.88 & 43.16 & 43.74 & 43.43 & 44.51 & 45.21 \\
$\mathrm{SiO}_{2}$ & 0.56 & 0.58 & 0.43 & 0.89 & 0.49 & 0.60 & 0.56 \\
$\mathrm{P}_{2} \mathrm{O}_{5}$ & 0.13 & 0.08 & 0.09 & 0.17 & 0.10 & 0.09 & 0.12 \\
$\mathrm{As}_{2} \mathrm{O}_{5}$ & 28.67 & 27.00 & 31.11 & 28.58 & 32.07 & 33.51 & 30.70 \\
$\mathrm{SO}_{3}$ & 0.04 & 0.04 & 0.27 & 0.16 & 0.03 & 0.10 & 0.07 \\
$\mathrm{H}_{2} \mathrm{O}^{*}$ & 15.28 & 15.24 & 15.27 & 15.29 & 15.26 & 15.33 & 15.26 \\
\hline $\mathrm{\Sigma} \mathrm{hm}_{4}$ & 99.16 & 96.16 & 100.47 & 99.99 & 102.22 & 105.06 & 102.51
\end{tabular}

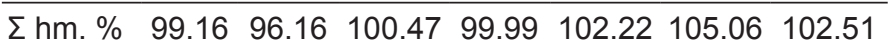
atómové koeficienty

\begin{tabular}{lccccccc}
\hline $\mathrm{Ca}^{2+}$ & 0.87 & 0.81 & 0.85 & 0.73 & 0.77 & 0.95 & 0.86 \\
$\mathrm{Fe}^{2+}$ & 0.07 & 0.07 & 0.07 & 0.08 & 0.06 & 0.06 & 0.07 \\
$\mathrm{Zn}^{2+}$ & 0.03 & 0.03 & 0.03 & 0.03 & 0.03 & 0.01 & 0.01 \\
$\mathrm{~Pb}^{2+}$ & 0.00 & 0.00 & 0.00 & 0.00 & 0.01 & 0.00 & 0.00 \\
$\mathrm{U}^{6+}$ & 0.05 & 0.06 & 0.04 & 0.06 & 0.03 & 0.04 & 0.05 \\
$\mathrm{Al}^{3+}$ & 0.02 & 0.01 & 0.01 & 0.04 & 0.09 & 0.03 & 0.01 \\
$\mathrm{Ti}^{4+}$ & 0.00 & 0.00 & 0.02 & 0.03 & 0.00 & 0.01 & 0.01 \\
$\mathrm{Y}^{3+}$ & 0.14 & 0.15 & 0.13 & 0.16 & 0.17 & 0.14 & 0.14 \\
$\mathrm{Nd}^{3+}$ & 0.01 & 0.01 & 0.02 & 0.01 & 0 & 0.01 & 0.01 \\
$\mathrm{Dy}^{3+}$ & 0.01 & 0.01 & 0.01 & 0.02 & 0.02 & 0.02 & 0.02 \\
\hline$\Sigma \mathrm{Y}^{+\mathrm{REE}}$ & 0.16 & 0.17 & 0.16 & 0.19 & 0.19 & 0.17 & 0.17 \\
\hline $\mathrm{Cu}^{2+}$ & 5.79 & 5.84 & 5.82 & 5.85 & 5.82 & 5.73 & 5.83 \\
$\mathrm{Si}^{4+}$ & 0.21 & 0.23 & 0.15 & 0.31 & 0.16 & 0.19 & 0.19 \\
$\mathrm{P}^{5+}$ & 0.02 & 0.01 & 0.01 & 0.03 & 0.01 & 0.01 & 0.02 \\
$\mathrm{As}^{5+}$ & 2.76 & 2.75 & 2.77 & 2.62 & 2.82 & 2.78 & 2.77 \\
$\mathrm{~S}^{6+}$ & 0.01 & 0.01 & 0.07 & 0.04 & 0.01 & 0.02 & 0.02 \\
$\mathrm{OH}^{++}$ & 5.08 & 5.1 & 5.21 & 5.13 & 5.19 & 5.11 & 5.12 \\
$\mathrm{H}_{2} \mathrm{O}$ & 3 & 3 & 3 & 3 & 3 & 3 & 3 \\
\hline
\end{tabular}

Normalizované na 10 atómov. $\mathrm{H}_{2} \mathrm{O}^{*}$ - obsah vody bol vypočítaný na základe ideálneho vzorca zálesíitu a vyrovnania nábojov.
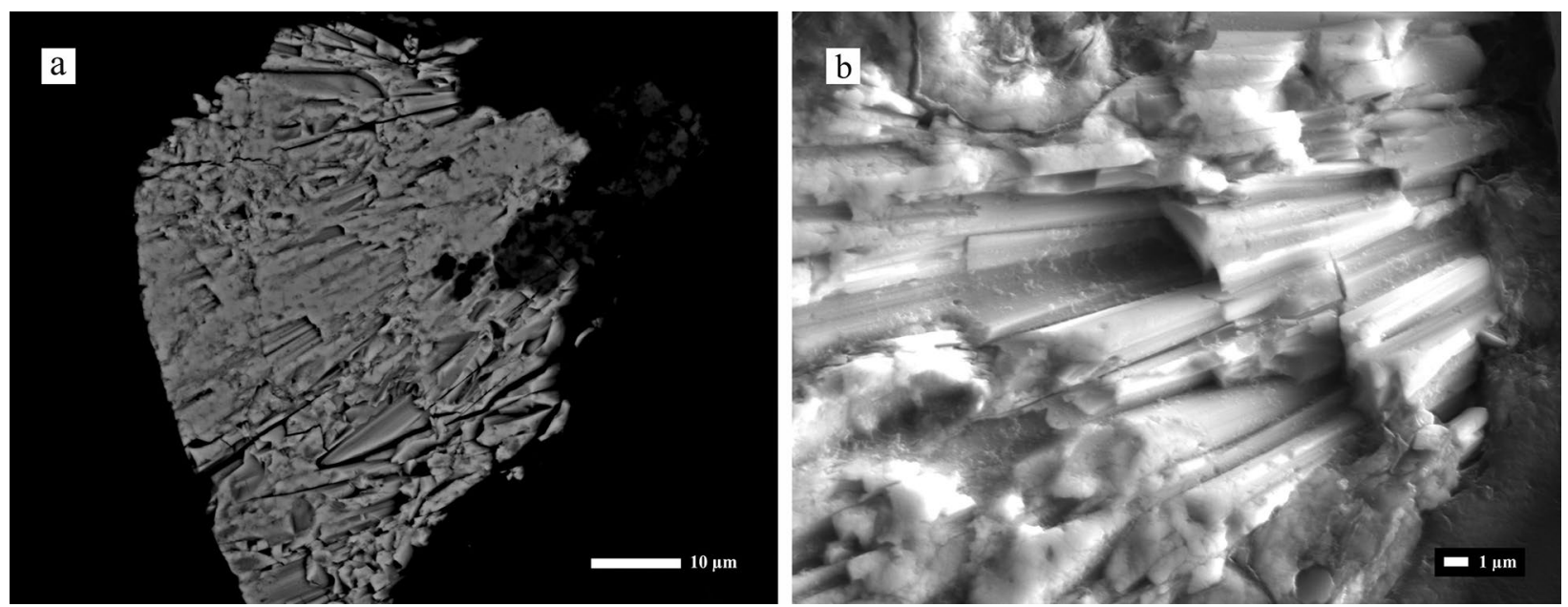

Obr. 7 a) Agregát ihlicovitých kryštálov zálesiitu. b) Detail obrázku a. BSE foto: T. Mikuš. 
ho uranofánu sú takmer identické s hodnotou pásu (3407 $\mathrm{cm}^{-1}$ ), ktorú uvádzajú Frost et al. (2006 a, b) a Čejka (in Burns, Finch 1999). DÍžka vodíkovej väzby vypočítaná na základe vzt'ahu publikovaného Libowitzskym (1999), sa pohybovala v rozmedzí $2.67-2.99 \AA$. V porovnaní s výsledkami prác Emsley (1980), Čejka, Urbanec (1990), Libowitzky (1999), Čejka (in Burns, Finch 1999) a Polák et al. (2016) možno konštatovat', že ide o slabú vodíkovú väzbu. Pásy na pozíciách $1800-1600 \mathrm{~cm}^{-1}$ prislúchajú deformačnej vibrácii $v_{2}(\delta)$ molekulárnej vody $\left(\mathrm{H}_{2} \mathrm{O}\right.$ s relatívne slabou väzbou $\vee$ štruktúre), zatial' čo pásy v spektrálnej oblasti $1600-1400 \mathrm{~cm}^{-1}$ sa objavujú v dôsledku napínania $\mathrm{H}_{2} \mathrm{O}$ väzby, súvisia však aj $\mathrm{s}$ deformačnou vibráciou $(\delta) \mathrm{SiOH}$ (Čejka, Urbanec 1990; Chernorukov, Kortikov 2002; Frost et al. 2006 a, b). Nevýrazný pás v oblasti $2650 \mathrm{~cm}^{-1}$ je pravdepodobne prejavom nečistôt organického pôvodu $\mathrm{v}$ analyzovanom materiáli.

Chemické zloženie uranofánu z Nižného Chmelienca je uvedené v tabul'ke 2 a obrázku 5. Študovaný uranofán je blízky ideálnemu vzorcu $\mathrm{Ca}\left(\mathrm{UO}_{2}\right)_{2}\left(\mathrm{SiO}_{3} \mathrm{OH}\right)_{2} \cdot 5 \mathrm{H}_{2} \mathrm{O}$ (Stohl, Smith 1981; Viswanathan, Harnett 1986). Okrem dominantných prvkov $\mathrm{Ca}, \mathrm{Si}, \mathrm{U}$ vstupujú na katiónovú pozíciu aj menšie množstvá $\mathrm{K}$ (do 0.01 apfu), Mg (0.02 apfu), Ba (do 0.01 apfu) a Fe (do 0.01 apfu; tab. 2). Priemerný empirický vzorec (14 bodových WDS analýz) uranofánu z Nižného Chmelienca možno vyjadrit' ako $\left(\mathrm{Ca}_{1.0} \mathrm{Mg}_{0.02} \mathrm{~K}_{0.01} \mathrm{Fe}_{0.01} \mathrm{Ba}_{0.01}\right)_{\Sigma 1.05}(\mathrm{U}$ $\left.\mathrm{O}_{2}\right)_{2.08}\left(\mathrm{SiO}_{3} \mathrm{OH}\right)_{1.84} \cdot 5 \mathrm{H}_{2} \mathrm{O}$. V porovnaní $\mathrm{s}$ uranofánmi $\mathrm{z}$ iných lokalít Slovenska možno konštatovat', že obsah $\mathrm{Ca}$ je $v$ tomto prípade len minimálne ovplyvnený prítomnost'ou draslíka, respektíve iných katiónov, na rozdiel napríklad od uranofánu zo Seliec, ktorý sa vyznačuje výraznejšou boltwooditovou substitúciou Ca $\leftrightarrow$ K (Polák et al. 2017; obr. 5). Uranofán z Kravan je zase charakteristický nižším obsahom Ca, ktorý je čiastočne substituovaný draslíkom. Banskoštiavnický uranofán (Števko et al. 2018) je charakteristický len minoritným obsahom prímesí a svojim zložením sa vel'mi podobá študovanému uranofánu.

(Meta)zeunerit (WDS) tvorí akcesóriu $\vee$ žltých až žltozelených povlakoch tvorených hlavne uranofánom. Ojedinele vytvára na povrchu hornín samostatné jemné povlaky tabul'kovitých kryštálov (vel'kost' do $0.5 \mathrm{~mm}$ ) svetlozelenej až smaragdovozelenej farby s perlet'ovým leskom (obr. 6), roztrúsené na ploche až $7 \times 5 \mathrm{~cm}$.

Na základe množstva (a aj vel'kosti zŕn) minerálnej fázy nebolo možné stanovit' obsah vody pomocou práškovej röntgenovej difrakcie. Je však preukázané, že pri bežných atmosferických podmienkach dochádza k dehydratácií zeuneritu za vzniku stabilnejšej metaformy - metazeuneritu. Vzhl'adom na uvedený fakt je vyslovene pravdepodobná prítomnost' metazeuneritu.

(Meta)zeunerit bol určený iba pomocou bodových vlnovodisperzných mikroanalýz (tab. 3). Okrem hlavných konštrukčných prvkov ( $\mathrm{U}, \mathrm{As}, \mathrm{Cu})$ boli $\mathrm{v}$ študovanom (meta)zeunerite zistené mierne zvýšené obsahy najmä $\mathrm{K}$ (0.02 - 0.04 apfu) a Fe 0.01 - 0.02 apfu) v katiónovej pozícii. Aniónová pozícia je dominantne obsadená As (1.95 - 2.04 apfu), vel'mi nevýrazné je zastúpenie P (0.01 apfu). Priemerné chemické zloženie (meta)zeuneritu z Nižného

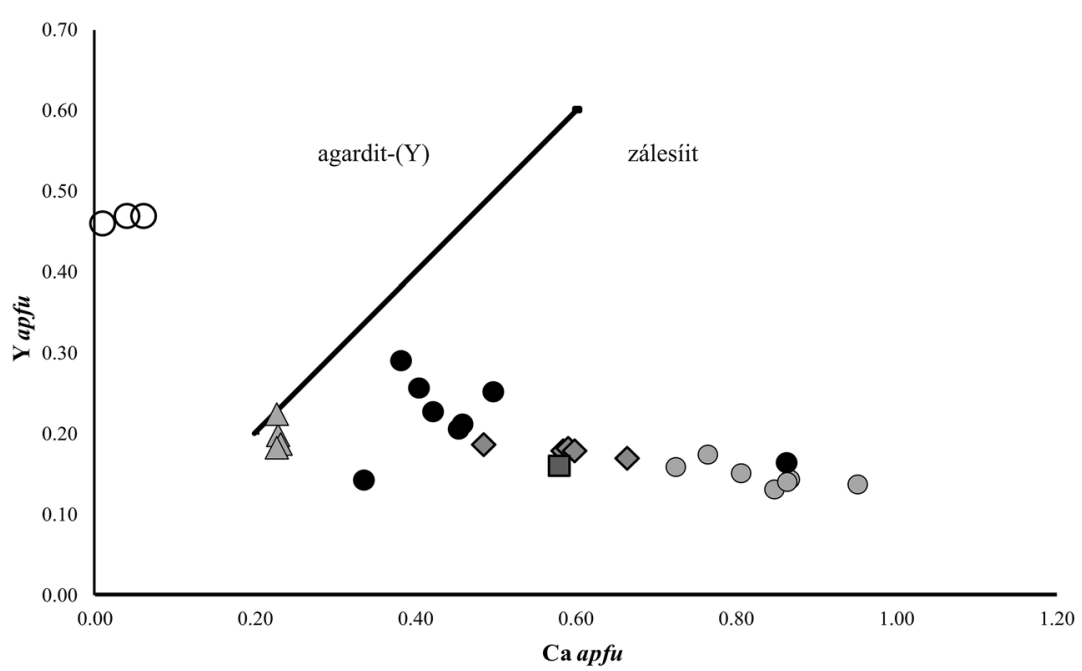

O zálesíit, Nižný Chmelienec (táto práca)

$\diamond$ zálesíit, Běloves (Sejkora et at. 2019)

○ agardit-(Y), Jáchymov (Plášil et al. 2014)

- zálesíit, Spišská Teplica (Ferenc et al. 2020)

$\square$ zálesíit, Lavrion (Pekov et al. 2011)

$\Delta$ agardit-(Y) / zálesíit, Medvědín (Plášil et al. 2009)

Obr. 8 Závislost' obsahu Ca vs. Y (apfu) študovaného zálesiitu v porovnaní s inými minerálmi mixitovej skupiny z vybraných lokalít.

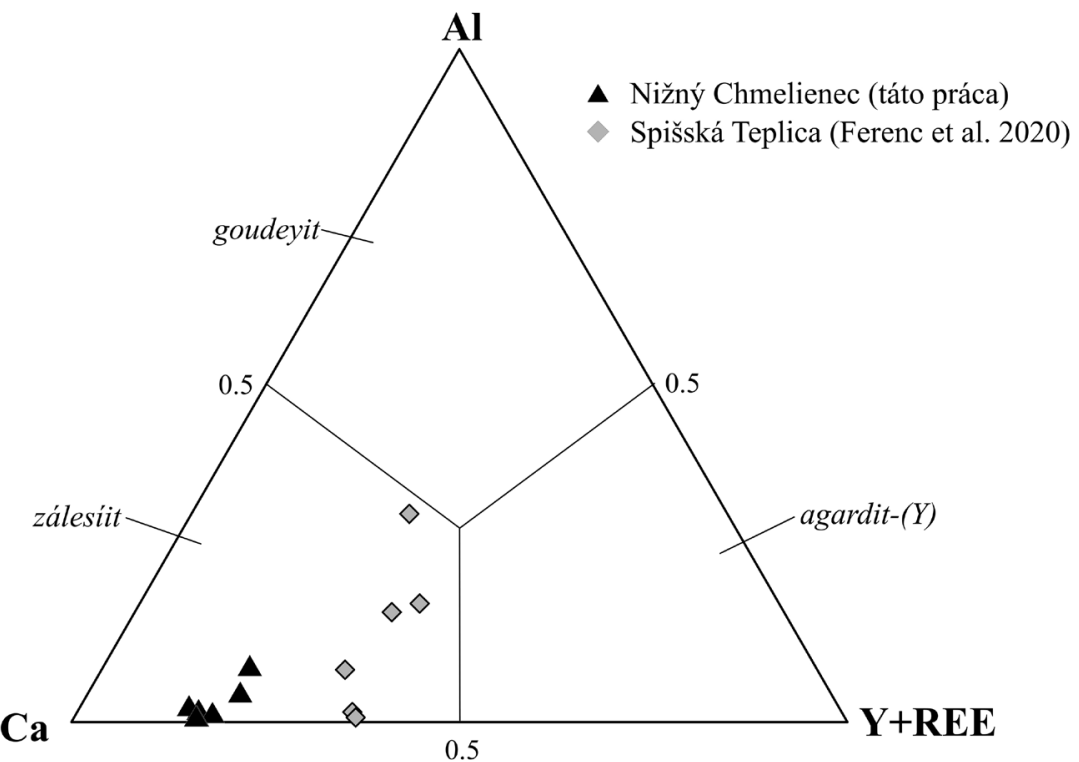

Obr. 9 Chemické zloženie zálesiitu zo Slovenska v systéme Al-Ca-Y+REE (apfu). 
Chmelienca ( 5 bodových WDS analýz) možno charakterizovat' ako $\left(\mathrm{Cu}_{0.66} \mathrm{~K}_{0.03} \mathrm{Fe}_{0.01} \mathrm{Ca}_{0.01}\right)_{\Sigma 0.71}\left(\mathrm{UO}_{2}\right)_{2.11}\left[\left(\mathrm{AsO}_{4}\right)_{1.96}\right.$ $\left.\left(\mathrm{PO}_{4}\right)_{0.01}\right]_{\Sigma 1.97} \cdot 12 \mathrm{H}_{2} \mathrm{O}$.

Zálesíit bol zistený pomocou WDS analýz ako d’alšia prímes povlakov a kôrok uranofánu. Tvorí jemné kryštalické agregáty, hniezda, zložené z ihlicovitých kryštálov s dížkou do $100 \mu \mathrm{m}$ (obr. 7a, b). Ide o druhý nález tohto minerálu na Slovensku.

Chemické zloženie minerálov skupiny mixitu možno vo všeobecnosti vyjadrit' chemickým vzorcom $\mathrm{ACu}_{6}$ $\left(\mathrm{TO}_{4}\right)_{3}(\mathrm{OH})_{6} \cdot 3 \mathrm{H}_{2} \mathrm{O}(\mathrm{Olmi}$ et al. 1991). V štruktúrnej pozícii A $\vee$ tomto prípade jednoznačne prevláda zálesítová molekula (0.73 - 0.95 apfu $\mathrm{Ca})$ nad ytrioagarditovou $(0.13$ - 0.17 apfu Y), plumboagarditovou (0.00 - 0.01 apfu $\mathrm{Pb}$ ) a goudeyitovou (0.01 - 0.09 apfu Al). Na aniónovej T-pozícii dominuje As (2.62 - 2.82 apfu) a Si (do 0.31 apfu), sprevádzané mierne zvýšenými obsahmi S (do 0.07 apfu) a $\mathrm{P}$ (do $0.03 \mathrm{apfu}$ ). Priemerné chemické zloženie (tab. 4) zálesíitu z Nižného Chmelienca možno na základe

Tabul'ka 5 Chemické zloženie baritu z rudného výskytu Východná - Nižný Chmelienec

\begin{tabular}{lrr}
\hline & 1 & 2 \\
\hline $\mathrm{BaO}$ & 62.41 & 62.51 \\
$\mathrm{SrO}$ & 1.53 & 1.77 \\
$\mathrm{Na}_{2} \mathrm{O}$ & 0.16 & 0.02 \\
$\mathrm{FeO}$ & 0.19 & 0.04 \\
$\mathrm{Al}_{2} \mathrm{O}_{3}$ & 0.23 & 0.00 \\
$\mathrm{SO}_{3}$ & 35.15 & 36.04 \\
\hline$\Sigma$ hm. \% & 99.67 & 100.38 \\
\hline atómové koeficienty & & \\
\hline $\mathrm{Ba}^{2+}$ & 0.93 & 0.92 \\
$\mathrm{Sr}^{2+}$ & 0.03 & 0.04 \\
$\mathrm{Na}^{+}$ & 0.01 & 0.00 \\
$\mathrm{Fe}^{3+}$ & 0.01 & 0.00 \\
$\mathrm{Al}^{3+}$ & 0.01 & 0.00 \\
$\mathrm{~S}^{6+}$ & 1.00 & 1.01 \\
\hline$\Sigma \mathrm{kat}$. & 1.00 & 0.96 \\
\hline $\mathrm{Ba} / \mathrm{S}$ & 0.93 & 0.91 \\
$\mathrm{Cat} / \mathrm{S}$ & 1.00 & 0.95 \\
\hline
\end{tabular}

Empirický vzorec bol prepočítaný na 4 kyslíky. siedmych bodových WDS analýz vyjadrit' nasledovným empirickým vzorcom: $\left(\mathrm{Ca}_{0.83} \mathrm{REE}_{0.18} \mathrm{U}_{0.05} \mathrm{Al}_{0.03} \mathrm{Ti}_{0.01}\right)_{\Sigma 1.10}$ $\left(\mathrm{Cu}_{5.81} \mathrm{Fe}_{0.06} \mathrm{Zn}_{0.02}\right)_{\Sigma 5.90}\left[\left(\mathrm{AsO}_{4}\right)_{2.75}\left(\mathrm{SiO}_{4}\right)_{0.21}\left(\mathrm{PO}_{4}\right)_{0.02}\left(\mathrm{SO}_{4}\right)_{0.03}\right]_{\Sigma 3.01}$ $(\mathrm{OH})_{5.10} \cdot 3 \mathrm{H}_{2} \mathrm{O}$. V chemickom zložení zálesíitu z Nižného Chmelienca explicitne dominuje Ca (zálesíitová molekula), na rozdiel od zálesíitu zo Spišskej Teplice, v ktorom je podstatne nižší obsah tejto zložky zapríčinený vyšším obsahom ytrioagarditovej molekuly (Ferenc et al. 2020; obr. 8). Na základe tohto faktu možno zálesíit zo Spišskej Teplice považovat' za hraničný typ zálesíitu v systéme mixitovej skupiny minerálov agardit-(Y) - zálesíit (obr. 9).

Malachit je na študovanej lokalite len podradne rozšíreným minerálom. Identifikovaný bol neštandardizovanou EDS analýzou. Tvorí tenké povlaky svetlozelenej farby na povrchu (plocha max. $0.5-1.5 \mathrm{~cm}^{2}$ ) a na puklinách hornín zložené z drobných ihlicovitých kryštálov dlhých maximálne do $5 \mu \mathrm{m}$.

Barit (WDS analýza) tvorí alotriomorfné zrná, s vel'kost'ou do $140 \mu \mathrm{m}$, prerastané/zatláčané, miestami lemované uranofánom (obr. 10a, b). Z prímesí je relatívne výraznejšie zvýšený iba obsah Sr, obsah ostatných prvkov je nepodstatný (tab. 5). Priemerný empirický vzorec baritu (2 bodové WDS analýzy) z Nižného Chmelienca je $\left(\mathrm{Ba}_{0.92} \mathrm{Sr}_{0.04} \mathrm{Na}_{0.01} \mathrm{Al}_{0.01}\right)_{\Sigma 0.98}\left(\mathrm{SO}_{4}\right)_{1.01}$.

\section{Diskusia a záver}

Študovaná asociácia U-Cu supergénnych minerálov je reprezentovaná uranofánom, (meta)zeuneritom, malachitom, v menšej miere sú zastúpené barit a zálesíit. Goethit je pomerne hojný $v$ podradných množstvách (nebol predmetom tohto štúdia). Minerály uranylu vznikli supergénnou alteráciou primárneho uraninitu (a sprievodných rudných i nerudných minerálov), v prostredí reliktu starej rudnej haldy na výskyte Východná - Nižný Chmelienec.

Uranofán ( ${ }^{6+}$ silikát) je jedným z najbežnejších uranylových minerálov typickým pre supergénne zóny uránových ložísk a výskytov (rozšírenie na viac ako 920 lokalitách po celom svete; databáza mindat.org; Frondel 1958; Stohl, Smith 1981; Viswanathan, Harnett 1986). $\checkmark$ rámci Slovenska bol doposial' identifikovaný na štyroch lokalitách vrátane študovaného výskytu: na ložisku stratiformnej U-Cu-Pb mineralizácie v permských pieskovcoch Kravany (Kozie Chrbty); na výskyte U-Cu mineralizácie $\checkmark$ permských arkózach ned'aleko obce Selce (Starohor-
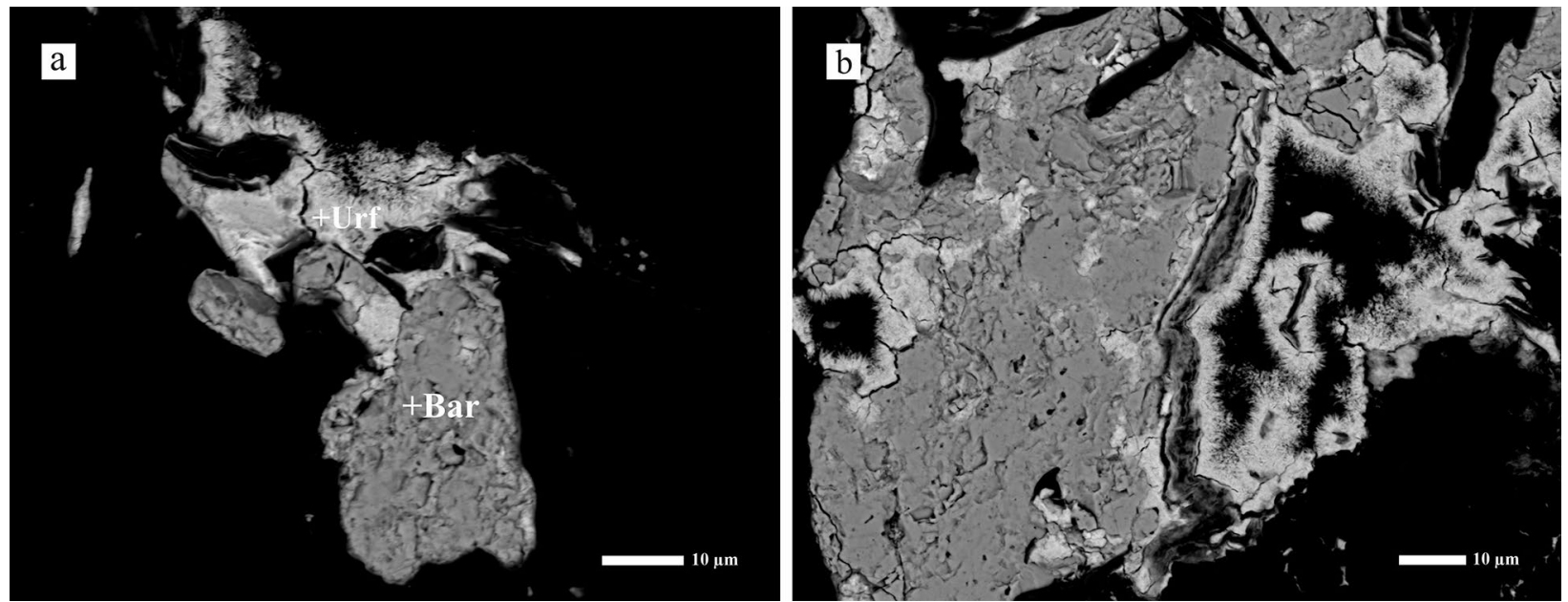

Obr. 10 a) Barit (Bar) zatláčaný uranofánom (Urf). b) Agregáty ihlicovitých kryštálov uranofánu (svetlosivý) lemujúce agregát baritu (tmavosivý). BSE foto: T. Mikuš. 
ské vrchy) a uranofán viazaný na U mineralizáciu v kremenno-kalcitovo-sulfidickej žile vyvinutej v hydrotermálne premenenom granodiorite $v$ Banskej Štiavnici (Koděra 1974; Rojkovič 1997; Ferenc et al. 2003; Polák et al. 2016; Števko et al. 2018; Hoppanová 2020). Uranofán vzniká počas pôsobenia alkalických - neutrálnych zvetrávacích podmienok $\mathrm{Eh}>0.2$ a pri $\mathrm{pH} \geq 7$ v prostrediach bohatých na Si ${ }^{4+}$ (Langmuir 1978; Finch, Ewing 1992; Finch, Murakami 1999; Kubatko, Burns 2006; Read et al. 2008; Krivovichev, Plášil 2013; Plášil 2018). Zdrojom Si, K a Ca potrebných pre tvorbu uranofánu na výskyte Východná - Nižný Chmelienec boli vylúhované horninotvorné minerály (sl'udy, živce, apatit) z arkóz.

Napriek tomu, že sú náleziská zálesíitu známe z celého sveta (93 lokalít; mindat.org), vzácne rozšírený zálesíit zo študovanej lokality je len druhým analyticky overeným výskytom na Slovensku, po lokalite Spišská Teplica (Ferenc et al. 2020). Zálesíit bol na oboch lokalitách rozšírený len v nepatrnom množstve a v mikroskopickej vel'kosti. Zdrojom Y, respektíve aj REE, sú bežné akcesórie prítomné v okolitých i hostitel'ských horninách (zirkón, monazit, xenotím; Rojkovič 1998). Na základe predpokladov Rojkoviča (1975) však podstatná čast' Y pravdepodobne pochádza z uraninitu, ktorý je menej odolný oxidačným procesom ako stabilnejšie a odolnejšie vyššie uvedené akcesórie (Plášil et al. 2009; Sejkora et al 2019; Ferenc et al. 2020).

Oxidačná zóna rudného výskytu Nižný Chmelienec je len nevýrazne vyvinutá a bol tu zistený len chudobnejší výskyt supergénnych minerálov U-Cu (Hoppanová 2020). Takýto stav naznačujú i staršie práce zamerané na študovanú lokalitu (Drnzík 1969; Rojkovič 1997, 1998). Na základe starších, vyššie uvedených prác je zrejmé, že v supergénnej zóne študovaného výskytu sú zastúpené iba uranylové fosfáty (autunit, torbernit). Paradoxom však je, že predložené výsledky výskumu supergénnej zóny rudného výskytu Východná - Nižný Chmelienec naopak preukázali fundamentálny výskyt práve silikátov uránu (reprezentovaných uranofánom) a len minoritné zastúpenie skupiny uranylových arzenátov (zeunerit/metazeunerit). V zmysle prác Dall'Aglio et al. (1974), Belova (1975, 2000), Finch, Murakami (1999) a Krivovichev, Plášil (2013) možno konštatovat', že vznik a vývoj asociácií uranylových minerálov, ako aj ich chemické zloženie a distribúcia, sú podmienené mnohými faktormi (napr. zloženie primárnej mineralizácie, fyzikálno-teplotné parametre hornín, podzemných vôd, klíma, atd'.). Proces oxidačných premien primárnych $\mathrm{U}^{4+}$ minerálov (uraninit, coffinit, brannerit...) a členenie supergénnej zóny sú detailne podané napríklad v prácach: Černikov (1981), Belova (1975, 2000), Krivovichev, Plášil (2013) a Plášil (2014).

Vznik recentnej supergénnej mineralizácie v Nižnom Chmielienci súvisí so zvetrávaním primárnych rudných minerálov U-Cu mineralizácie - najmä sulfidov (pyrit, galenit, chalkopyrit) a uraninitu (Rojkovič 1997, 1998). Uvol'nenie kyseliny sírovej pri rozklade sulfidov spôsobuje rozpúšt'anie a oxidáciu uraninitu (obohatenie supergénnych roztokov o mobilný katión $\mathrm{UO}_{2}{ }^{2+}$ ) a zároveň privádza do roztoku aj mnohé iné prvky a anióny, $v$ tomto prípade $\mathrm{Cu}, \mathrm{Ca}, \mathrm{Si}, \mathrm{P}, \mathrm{As}, \mathrm{Y}$ a i. (Finch, Ewing 1992; Rojkovič 1998; Števko et al. 2012; Krivovichev, Plášil 2013; Plášil 2014; Ferenc et al. 2018; Hoppanová 2020). Vznik uranylových silikátov (uranofánu) a minerálov skupiny mixitu (zálesíit) prítomných na študovanej lokalite, teda môže naznačovat' neutralizáciu kyslých supergénnych fluíd, prípadne prechod charakteru prostredia do ne- utrálneho až mierne zásaditého, čo indikuje prítomnost' karbonátov (malachit). Fosfáty/arzenáty uranylu (zeunerit/metazeunerit), typické pre kyslé prostredie sú preto vzácnejšie. Uvedený predpoklad modelu vývoja supergénnych zón U rúd výskytu Východná - Nižný Chmelienec je $v$ dobrej zhode so schémou publikovanou $\vee$ práci Krivovicheva, Plášila (2013).

\section{Pod'akovanie}

Tento príspevok mohol vzniknút' vd'aka finančnej podpore grantových štruktúr VEGA1/0237/18, APVV 19-0065 a projektu ITMS 26210120024 Obnova a budovanie infraštruktúry pre ekologický a environmentálny výskum na UMB. Za podrobné preštudovanie textu a pripomienky, ktoré výrazne skvalitnili rukopis d’akujeme recenzentom Jiř́mu Čejkovi a Martinovi Števkovi.

\section{Literatúra}

BARTLETT JR, COONEY RP (1989) On the determination of uranium-oxygen bond lengths in dioxouranium (IV) compounds by Raman spectroscopy. J Mol Struct 193: $295-300$

BELova LN (1975) Zony okislenija gidrotermal'nych mestoroždenij urana. 1-173, Nedra, Moskva

BELOVA LN (2000) Formation conditions of oxidation zones of uranium deposits and uranium mineral accumulations in the gipergenesis zone. Geol Ore Dep 42: 103110

Biely a, Beňuška P, Bezák v, Bujnovský A, Halouzka R, IvaNIČKA J, KOHÚt M, KLINEC A, LUKÁČIK E, MAgLAY J, MIKo O, Pulec M, Putıš M, VozÁr J (1992) Geologická mapa Nízkych Tatier, 1 : 50 000. ŠGÚDŠ Bratislava

Butı D, Rosı F, BRunetTI BG, MILIANI C (2013) In-situ identification of copper-based green pigments on paintings and manuscripts by reflection FTIR. Anal Bioanal Chem 405: 2699-2711

Colmenero F, Timón V, Bonales LJ, Cobos J (2018) Structural, mechanical and Raman spectroscopic characterization of the layered uranyl silicate mineral, uranophane- $\alpha$, by density functional theory methods. Clay Miner 53: 337-392

ČEJKA J (1999) Infrared spectroscopy and thermal analysis of the uranyl minerals. In Burns PC, Finch R (ed.) Uranium: Mineralogy, Geochemistry and the Environment: 521-622. Mineral Soc Of America, Washington

ČEJKA J, URBANEC Z (1990) Secondary uranium minerals: The Mineralogy, Geochemistry and Crystal Chemistry of the Secondary Uranium (VI) Minerals. 68-70, Academia, Nakladatelství ČSAV, Praha

Dall`Aglio M, Craigini R, Locardi E (1974) Geochemichal factors controlling the formation of the secondary minerals of uranium. In: Formation of Uranium Ore Deposits: 33-48, International Atomic Energy Agency, Vienna

DANIEL J (1999) Záverečná správa: Revízne a ukončujúce práce na rádioaktívne suroviny, Čiastková správa: Zhodnotenie geologických prác na $U$ rudy $v$ oblasti stredoslovenských neovulkanitov. Ministerstvo životného prostredia SR, sekcia geológie a prírodných zdrojov. Bratislava URANPRES - s.r.o. Spišská Nová Ves, 195

DrNZík E (1969) O zrudnení typu med'natých pieskovcov v perme melafýrovej série na severovýchodných svahoch Nízkych Tatier. Miner Slov 1: 7-38

EMSLEY J (1980) Very strong hydrogen bonding. Chem Soc Rev 9: 91-124 
FERENC Š (2002) Uranium mineralization in the Permian volcanic rocks at the Kravany, Kozie chrbty Mts. Western Carpathians, Slovac Republic-information. In: Uranium Deposit: From their genesis to thier environmental aspect: $49-52$

FERENC Š (2018) Výskum vybraných genetických typov mineralizácie vo veporskom pásme (veporikum, hronikum). Habilitačná práca. PRF UK, Bratislava, 56

Ferenc Š, Biroñ A, SeJKora J, Sýkorová M (2017) Fosfouranylit z oxidačnej zóny žilnej kremenno-apatitovo -REE-U mineralizácie v Majerskej doline pri Čučme (Slovenské rudohorie, gemerikum). Bull Mineral Petrolog 25: 23-32

FERENC Š, BIRoŇ A, MIKuš T, SPIŠIAK J, BudZÁk Š (2018) Initial replacement stage of primary uranium (U'V) minerals by supergene alteration: association of uranyl-oxide hydroxy-hydrates and "calciolepersonnite" from the Krátka Dolina Valley (Gemerská Poloma, Gemeric Unit, Western Carpathians, Slovakia). J Geosci 63: 277-291

Ferenc Š, Hoppanová E, Kopáčik R, Mikuš T, Budzák Š (2020) Supergénne minerály stratiformnej U-Cu mineralizácie pri Spišskej Teplici (hronikum, Kozie chrbty, východné Slovensko). Bull Mineral Petrolog 28: 295-306

FERENC Š, MIKUŠ T, SPIŠIAK J, MILOVSKÁ S (2019) Supergene minerals in quartz \pm fluorapatite hydrothermal veins with U-Mo and U-REE mineralization near Čučma (Gemeric Unit, Western Carpathians, eastern Slovakia): preliminary study. In: ONDREJKA M, FRIDRICHOVÁ J (eds.), Mineralogicko-petrologická konferencia Petros 2019, Zborník recenzovaných abstraktov a príspevkov (29.-30. máj 2019): 17-19. UK Bratislava

FERENC Š, RoJkovič I, MAŤo L' (2003) Uranylové minerály Západných Karpát. Zbor konf Mineralogie Českého masívu a Západných Karpát (Olomouc a Horní Údolí): 17-23. Univerzita Palackého Olomouc

FINCH R, MuRAKamı T (1999) Systematics and paragenesis of uraniu minerals. In: BURNS PC, FINCH R (ed.), Uranium: Mineralogy, Geochemistry, and the Environment: 91-179. Mineralogical Society of America, Washington, DC.

FINCH RJ, EwING RC (1992) The corrosion of uraninite under oxidizing conditions. J Nucl Mater 190: 133-156

FRONDEL C (1958) Systematic mineralogy of uranium and thorium. US Geol Survey Bull 1064: 1-400

Frost RL, Čejka J, Weier ML, Martens WN (2006a) Molecular structure of the uranyl silicates - a Raman spectroscopic study. J Raman Spectrosc 37: 538-551

Frost RL, ČEJKa J, Weier ML, Martens WN (2006b) Raman spectroscopy study of selected uranophanes. J Mol Struct 788: 115-125

GAO J, YUAN X (2020) Vibrational investigation of pressure-induced phase transition of hydroxycarbonate malachite $\mathrm{Cu}_{2}\left(\mathrm{CO}_{3}\right)(\mathrm{OH})_{2}$. Minerals 10: 14

HoPPANOVÁ E (2020) Supergénne alterácie stratiformnej $\mathrm{U}-\mathrm{Cu}$ mineralizácie $\mathrm{v}$ mladšom paleozoiku hronika Kozích chrbtov a Nízkych Tatier. MS, diplomová práca, FPV UMB Banská Bystrica, 88

ČERNIKov AA (1981) Povedenie urana v zone gipergeneza. 1-208, Nedra, Moskva

Chernorukov NG, Kortikov VE (2002) Synthesis and study of $\mathrm{Sr}\left[\mathrm{HSiUO}_{6}\right]_{2} \cdot 2 \mathrm{H}_{2} \mathrm{O}$ and $\mathrm{Ba}\left[\mathrm{HSiUO}_{6}\right]_{2} \cdot 2 \mathrm{H}_{2} \mathrm{O}$. Radioch 44: 446-451

KODĚRA M (1974) Mineralógia rádioaktívnych minerálov a ich vzt'ah $\mathrm{k}$ polymetalickej mineralizácii $v$ stredoslovenských neovulkanitoch. MS, ŠGÚDŠ - Geofond Bratislava Eč. 57411
KOPÁČIK R, FERENC Š (2017) Uránová mineralizácia pri Brezne (veporikum): predbežné výsledky. Zbor konf PETROS 2017 (Bratislava): 24-27. Univerzita Komenského Bratislava

KRIVOVICHEV S, PLÁšIL J (2013) Mineralogy and crystallography of uranium. In: Burns PC, Sigmon GE (2013) Uranium: From Cradle to Grave. Canada: Mineralogical Association of Canada Short Courses 43: 15-119

KubatKo KA, Burns PC (2006) A novel arrangement of silicate tetrahedra in the uranyl silicate sheet of oursinite, $\left(\mathrm{Co}_{0.8} \mathrm{Mg}_{0.2}\right)\left[\left(\mathrm{UO}_{2}\right)\left(\mathrm{SiO}_{3} \mathrm{OH}\right)\right]_{2}(\mathrm{H} 2 \mathrm{O})_{6}$. Am Mineral 91: 333-336

Lafuente B, Downs RT, Yang H, Stone N (2015) The power of databases: the RRUFF project. In: Armbruster T, Danisi RM (eds.): Highlights in Mineralogical CrystaIlography, 1-30. W. De Gruyter Berlin

LANGMUIR D (1978) Uranium solution-mineral equilibria at low temperatures with applications to sedimentary ore deposits. Geochim Cosmochim Acta 42: 547-569

LIBOWITZKY E (1999) Correlation of O-H stretching frequencies and $\mathrm{O}-\mathrm{H} \cdots \mathrm{O}$ hydrogen bond lengths in minerals. Monatsh Chem 130: 1047-1059

Miliani C, Rosi F, Daveri A, Brunetti BG (2012) Reflection infrared spectroscopy for the non-invasive in situ study of artists' pigments. Appl Phys A 106: 295-307

Mindat. Prístup 11.8. 2020 na adrese https://www.mindat. org/min-7026.html

NovotnÝ L, BADÁR J (1971) Stratigrafia, sedimentológia a zrudnenie mladšieho paleozoika severovýchodnej časti Nízkych Tatier. Miner Slov 3: 23-36

Olmi F, Sabelli C, Trostı FR (1991) A contribution to the crystal chemistry of mixite group minerals from Sardinia (Italy). N Jb Miner, Mh: 487-499

Pekov I, Chukanov NV, Zadov AE, Voudouris P, Magganas A, Katerinopoloulos A (2011) Agardite-(Nd) $\mathrm{NdCu}_{6}$ $\left(\mathrm{AsO}_{4}\right)_{3}(\mathrm{OH})_{6} \cdot 3 \mathrm{H}_{2} \mathrm{O}$ from the Hilarion Mine, Lavrion, Greece: Mineral description and chemical relations with other members of the agardite-zálesíte solid-solution system. J Geosci 56: 249-255

PLÁŠIL J (2018) Structural complexity of uranophane and uranophane- $\beta$ : implications for their formation and occurence. Eur J Miner 30: 253-257

PLAŠIL J, HLouŠEK J, KASATKIN A (2014) Pozoruhodný výskyt metat'ujamunitu a minerálů mixitové skupiny na Dušní žíle (Geister), Jáchymov (Česká republika). Bull Mineral Petrolog Odd Nár Muz (Praha) 22: 215-220

PLÁšIL J, SEJKORA J, ČEJKA J, ŠKoda R, GoliÁš V (2009) Supergene mineralization of the Medvědín uranium deposit, Krkonoše Mountains, Czech Republic. J Geosci 54: $15-56$

PolÁk L', FERENC Š, Biroñ A, SÝkORová M (2016) Uranofán zo Seliec pri Banskej Bystrici (Starohorské vrchy, Slovenská republika). Bull Mineral Petrolog 24: 178-182

Polák L', Ferenc Š, MıKuš T, SEJKora J (2017) Nové údaje o uranylových mineráloch z lokality Selce pri Banskej Bystrici (severné veporikum, Slovenská republika). Bull Mineral Petrolog 25: 162-169

Read K, Black S, Buckby T, Hellmuth KH, Marcos N, Siltari -KAUPPI M (2008) Secondary uranium mineralization in southern Finland and its relationship to recent glacial events. Global Planet Change 60: 253-249

RoJkovıč I (1975) Geochemical characterization of U-Cu $-\mathrm{Pb}$ mineralization in the Permian of the Choč Nappe in the Vikartovský chrbát area. Geol Zbor Geol Carpath 26: 105-114 
RoJkovıč I (1995) Uránová mineralizácia v permských horninách Západných Karpát. Habilitačná práca, Bratislava 1995

RoJkovıč I (1997) Uranium mineralization in Slovakia. 1-117, Comenius University, Bratislava

RoJkovıč I (1998) Stratiformná U-Cu mineralizácia v perme Nízkych Tatier. Miner Slov 30: 66-71

SEJKORA J, ŠKÁCHA P, ČEJKA J (2019) REE-bohatý zálesíit z Bělovsi u Náchoda (Česká republika). Bull Mineral Petrolog 27: 297-303

SpectraBase. Prístup 25. 9. 2020 na adrese http:// spectrabase.com/spectrum/ENIrYngNX61

SCHMIDT M, LUTZ HD (1993) Hydrogen bonding in basic copper salts: a spectroscopic study of malachite, $\mathrm{Cu}_{2}(\mathrm{OH})_{2} \mathrm{CO}_{3}$, and brochantite, $\mathrm{Cu}_{4}(\mathrm{OH})_{6} \mathrm{SO}_{4}$. Phys Chem Miner 20: 27-32

Stollova D, Koleva V, Vassileva V (2002) Infrared study of some synthetic phases of malachite $\left(\mathrm{Cu}_{2}(\mathrm{OH})_{2} \mathrm{CO}_{3}\right)$ - hydrozincite $\left(\mathrm{Zn}_{5}(\mathrm{OH})_{6}\left(\mathrm{CO}_{3}\right)_{2}\right)$ series. Spectrochim Acta A 58: 2051-2059

SToHL FV, Sмiтн DK (1981) The crystal chemistry of the uranyl silicate minerals. Am Mineral 66: 610-625
Števko M, Sejkora J, Malíková R (2018) Nové údaje o supergénnych mineráloch z ložiska Banská Štiavnica (Slovenská republika). Bull Mineral Petrolog 26: 90 101

ŠteVko M, SeJKora J, PLÁŠIL J (2012) Supergénna uránová mineralizácia na ložisku Banská Štiavnica (Slovenská republika). Bull mineral-petrolog Odd Nár Muz (Praha) 20: $110-120$

Tulis J, Novotný L (1998) Zhodnotenie geologických prác na $U$ rudy $v$ mladšom paleozoiku hronika $v$ severnej časti Nízkych Tatier a Kozích chrbtov. MS, archív ŠGÚDŠ - Geofond Bratislava Eč. 82752

VESELÝ Z, BADÁR J (1984) Malá uránová ložiská v Západných Karpatoch. Geol Hydrometal Uran 8: 3-36

VisWANATHAN K, HARNETT O (1986) Refined crystal structure of beta-uranophane, $\mathrm{Ca}\left(\mathrm{UO}_{2}\right)_{2}\left(\mathrm{SiO}_{3} \mathrm{OH}\right)_{2} \cdot 5 \mathrm{H}_{2} \mathrm{O}$. Am Mineral 71: 1489-1493

VozÁrová A, VozÁr J (1988) Late Paleozoic in West Carpathians. 1-314, Geol Inst of D. Štúr, Bratislava 